\title{
On the Incoherence of the Universal Rule and the Theoretical Impossibility of a Contradiction between Reason and Revelation
}

\author{
Ibn Taymiyya on the Universal Rule and the Variety of Responses \\ It Has Elicited
}

In the year 6o6/1209, fifty-four years before the birth of Ibn Taymiyya, the great Persian Ash'‘arī theologian Fakhr al-Dīn al-Rāzī passed away, leaving behind a massive body of writings. ${ }^{1}$ Many of these writings were theological tracts aimed specifically at buttressing the position of the more textually conservative Ash'arī school of theology against the more rationalistically inclined $\mathrm{Mu}^{\mathrm{C} t a z i l a}$. In one of his more influential theological treatises, Asās al-taqdīs, ${ }^{2}$ al-Rāzī enunciates a so-called universal rule (qānūn kullī), a plea from Ash'arī theologians for a truce in the ongoing battle between reason and revelation. By al-Rāzìs time, this universal rule had won the approval of the majority of his Asharī colleagues, whose doctrine was steadily becoming the standard formulation of Islamic belief, expressed in rationalistic terms, throughout much of the Islamic world. ${ }^{3}$

The universal rule, as paraphrased by Ibn Taymiyya at the beginning of the Dar' ta $^{\top} \mathrm{arud},{ }^{4}$ states:

If scriptural and rational indications, or revelation and reason, or the obvious outward meaning of the revealed texts and the definitive conclusions

1 A summarized version of this chapter has appeared previously as El-Tobgui, "Ibn Taymiyya on the Incoherence of the Theologians' Universal Law." Note the change in terminology from "Universal Law" in the article to "universal rule" for "al-qānūn al-kullī" in the current work.

2 TariqJaffer points out that al-Rāzī refers to this work, which is devoted entirely to the question

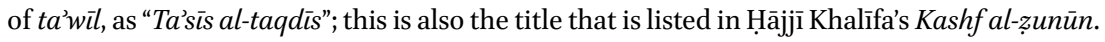
See Jaffer, Rāzī, 58-59, n. 19; Ḥājjī Khalīfa, Kashf al-zunūn, 1:333.

3 For an overview of Ash'arī principles of figurative interpretation $\left(t a^{\prime} w \bar{\imath} l\right)$ from al-Juwaynī to al-Jurjānī in the face of conflicting rational and scriptural evidence, see Heer, "Priority of Reason," 181-188.

4 For a discussion of earlier statements of this rule in al-Ghazālī and al-Rāzī and the relationship of Ibn Taymiyya's paraphrase of the rule in the Dar' to these antecedents, see Griffel, "Ibn Taymiyya and His Asharite Opponents," $15-30$. 
of rational thought - or other ways of phrasing it—are in conflict, then either (1) they must both be accepted, which is impossible as this would violate the law of non-contradiction [claiming both $p$ and $-p$ ]; (2) they must both be rejected [which is also impossible as this would violate the law of the excluded middle (claiming neither $p$ nor $-p$ )]; or (3) precedence must be given to revelation, which is impossible since revelation is grounded in reason, such that if we were to give priority to the former over the latter [that is, to revelation over reason], this would amount to a rejection of both reason and [by extension] that which is grounded in reason [namely, revelation]. One must, therefore, (4) give precedence to reason over revelation, then either interpret revelation figuratively [to accord with reason] ( $\left.t a^{2} w \bar{l} l\right)$ or negate the apparent meaning of revelation but refrain from assigning to it a definite, particular metaphorical meaning (tafwì $)^{5}{ }^{5}$

Ibn Taymiyya cites an alternative formulation of this rule given by al-Rāzī in another work, Nihāyat al-'uqūl fì dirāyat al-uṣūl, in which al-Rāzì adds a significant detail—central to Ibn Taymiyya's overall concern in the Dar' — namely, that "(the truth of) revelation can be established only through rational means, for it is only through reason that we can establish the existence of the Creator and know (the authenticity of) revelation." ${ }^{\prime 6}$ Ibn Taymiyya laments that al-Rāzī and his followers have made this into a universal rule for interpreting revelation as it relates to God's attributes and other issues in which they deem reason to be in contradiction with what scripture affirms. Some of them-including al-Rāzī

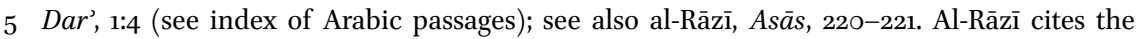
same basic principle in similar terms in other works as well. See, e.g., al-Rāzī, Mațālib, 9:116117; Muhasșal, 51; Nihāyat al-'uqūl, 1:143; Arba'ìn, 1:163-164; Masāill, 39-40; Ma'ālim, 48; and Mafātīh, 22:6-7. See Heer, "Priority of Reason," 184-185 for an English translation and discussion of the passages given here from al-Rāzì's $A s \bar{a} s$ and Masāill. See Jaffer, Rāzī, 89-94 for a translation and discussion of these same two passages, as well as the passage cited here from Mafātīh. On tafwìu, see Abrahamov, "Bi-lā Kayfa' Doctrine." On the universal rule, see also Adem, "Intellectual Genealogy," 210-229.

6 Cited at Dar', 5:331, lines 2-4 (emphasis mine). See al-Rāzī, Nihāyat al-'uqūl, 1:143 and similar at al-Rāzī, Masāill, 39-40. For statements by other major Ash'arī theologians to the effect that reason is the only means by which the authority of revelation can be established, see, for example, 'Abd al-Qāhir al-Baghdādī, Kitāb Ușūl al-dīn, 23; al-Juwaynī, Irshād, 358-36o; and al-Ghazālī, Iqtișād, 115. For English translations of the passages indicated in this note from alJuwaynī's Irshād and al-Ghazālì's Iqtișād, see Heer, "Priority of Reason," 185-186. For a more expansive list of sources-including the writings of figures such as Shams al-Dīn al-Așfahānī (d. 749/1349), al-Taftāzānī (d. 793/139o), and al-Jurjānī (d. 816/1413), as well as Mu'tazilīs who also held this doctrine-see Heer, "Priority of Reason," 193, n. 21 and 194, n. 22. 
himself-add to this the notion that scriptural indicants (adilla samiiyya) are, in fact, inherently incapable of engendering certainty and therefore cannot be relied upon in matters of definitive knowledge. ${ }^{7}$ Ibn Taymiyya remarks that others before them had already articulated this universal rule, such as al-Ghazālī, who employed it in his short treatise Qānūn al-ta wīl ${ }^{8}$ to answer questions posed to him by some of his students, such as Abū Bakr b. al-'Arabī. Ibn al'Arabī, in turn, articulated an alternative formulation of the rule in a lengthy work of the same title, ${ }^{9}$ basing himself on the method followed by al-Ghazālìs

7 See, for example, Dar', $^{\prime}$ 5:335, lines 2-3, where Ibn Taymiyya cites a passage from al-Rāzì's Nihāyat al-'uqūl, a few pages after his statement of the universal rule cited above, to the effect that "transmitted textual indicants (adilla naqliyya) cannot be relied upon in matters of (definitive) knowledge (al-adilla al-naqliyya lā yajüzu al-tamassuk bihā fì al-masāil al-'ilmiyya)." See al-Rāzī, Nihāyat al-'uqūl, 1:146 (where, however, al-Rāzī has "al-masāil al'aqliyya," not "al-masāil al-'ilmiyya"). See also al-Rāzī, Ma'ālim, 25; Muhașșal, 51; and Arba'ìn, 2:253-254 (where, however, al-Rāzī states that textual indicants can yield certainty if backed up by mutawātir reports; see similar at al-Rāzī, Mațālib, 9:117). For further discussion of alRāzī's views on revelation and certainty, see El-Tobgui, "Hermeneutics of Fakhr al-Dīn alRāzī," 139-140 and, more extensively, Jaffer, Rāzī, 77-83 and 102-104. Notwithstanding al-Rāzìss qualification (in works such as Arbain and Mata àlib) about the ability of scriptural indicants to yield certain knowledge if corroborated by tawātur, Jaffer concludes-primarily on the basis of Asās, Mafātīh, and Ma'ālim - that al-Rāzĩ fundamentally denies the possibility that even mutawātir reports can engender certitude (see Jaffer, 8o-83), thus assigning "even the strongest of hadith reports a low epistemic value" (Jaffer, 82). (These conclusions thus concur with the earlier findings of Goldziher, "Aus der Theologie," 230-237 and Arnaldez, "L' œuvre," 315.) Jaffer observes further that the radical nature of al-Rāzìs skepticism vis-à-vis ḥadīth was matched only by the "maverick Mu'tazilite" Abū Isḥāq al-Nazzạām (d. between 220/835 and 230/845), the "only thinker who expresses such a degree of doubt about prophetic reports" and whose "views were considered radical even by Mu'tazilite standards" (Jaffer, 81, n. 71 and 83, n. 77). Van Ess credits Ibn Taymiyya with having possessed a "well-informed insight" into the discussions that had taken place regarding the probity and proof value of scriptural indicants, specifically in his work al-Furqān bayna al-haqq wa-lbāțil. See van Ess, Die Erkenntnislehre des 'Adudaddin al-İci, 409. Ibn Taymiyya, van Ess tells us, knew that al-Rāzī was among those who "polemicized most strongly against scriptural proofs," which he held to be fundamentally inconclusive (van Ess, 409). On these grounds, van Ess likewise characterizes al-Rāzìs position as an "extreme case" (ein Extremfall) (van Ess, 410).

8 Al-Ghazālī, Qānūn al-ta’wīl, 19, 21. Related discussions can be found in al-Ghazālī, Iqtișād, 116 and al-Ghazālī, Fayșal al-tafriqa, 47-48. (For a translation of and an introduction to Fayșal al-tafriqa, see Jackson, On the Boundaries.) For a presentation and analysis of alGhazālì's approach to metaphorical interpretation, see Griffel, Al-Ghazāl’’s Philosophical Theology, 111-122 (esp. 111-116) and, more expansively, Griffel, "Al-Ghazālī at His Most Rationalist." For a translation of al-Ghazālì's Qānūn al-ta’wīl, see Heer, "Al-Ghazali: The Canons of Ta'wil."

9 See Abū Bakr b. al-'Arabī, Qānūn al-ta’wīl, 646-647. See also Abū Bakr b. al-'Arabī, al-'Awāṣsim min al-qawāṣim, 231. 
teacher, al-Juwaynī, ${ }^{10}$ and those before him such as al-Bāqillānī. ${ }^{11}$ In sum, Ibn Taymiyya explains, every school of thought has established for itself an analogous rule: they take as true and objective knowledge what they deem to know on the basis of reason, then they subordinate revelation to this alleged "knowledge" and (re)interpret it accordingly.

Such reinterpretation of revelation as prescribed by the universal rule has conventionally been carried out in one of two ways: through (1) figurative interpretation, or $t a^{2} w \bar{l} l$, which is normally defined as assigning to a revealed text a meaning other than its overt or obvious (zāhir) sense in accordance with a conclusion reached through reason, or through (2) suspension of meaning, or tafwied, normally defined as declaring the obvious meaning of a text invalid but refraining from providing any specific alternative interpretation, consigning ("tafwi $d^{\prime \prime}$ ) its true meaning to God instead. Ibn Taymiyya subsumes both ta'will and tafwi d under a larger dichotomy composed of what he refers to as "alteration of meaning" (tabdīl), on the one hand, and "presumption of ignorance and misguidance" (tajhïl and tadlīl), on the other. Tabdīl, in turn, comprises two sub-varieties: (a) "wahm and takhyil" and (b) "tahrîf and ta'will."

The first method of alteration of meaning, that of wahm and takhyll, presupposes revelation to consist mainly of images and metaphors that, by design, do not correspond to the actual reality of metaphysical matters such as the nature of God, angels, and other unseen realities, or the eschatological realities of heaven and hell. Rather, according to this view, revelation purposely induces men to conceive of God as consisting of an enormous body, to believe in the literal resurrection of bodies after death, physical rewards and punishments in the hereafter, and so on, as it is in the moral interest (mașlaha) of the common people to be addressed in such a way. Indeed, it is only in this manner that they can successfully be called to religion and that their ultimate otherworldly benefit, which is consequent upon their acceptance of religion,

10 See, for instance, al-Juwaynī, Irshād, 358-36o.

11 See, for instance, al-Bāqillānī, Tamhìd, 259, where we read that "it is necessary to divert speech from its apparent meaning if rational and scriptural indicants rule out its being used in accordance with its primary sense" (innamā yajibu șarf al-kalām 'an żăhirihi idhā kānat dalāil al-'aqlwa-l-sam' tamna'u isti'mālahu 'alà mā warada bihi). Ibn Taymiyya generally thinks very highly of al-Bāqillānī, no doubt since he was close in time to al-Ash'arī and therefore still recognizably part of the early Ash'arīs, or "mutaqaddimūn" (with alJuwaynī seen as the bridge to the later doctrine). The universal rule (al-qānūn al-kullī or qānūn al-ta'wīl) — as later articulated by the likes of al-Juwaynī, al-Ghazālī, and al-Rāzīdoes not appear in an explicitly crystallized form in al-Bāqillānī, though the idea and principle of $t a^{\prime} w i ̈ l$ are present (as in the citation from Tamhìd given here). See the comments of Muḥammad Sulaymān (ed.) in Abū Bakr b. al-'Arabī, Qānūn al-ta'wūl, 246. 
can be assured. Among others, Ibn Taymiyya faults Ibn Sīnā for endorsing this kind of tabdil (alteration of meaning) in his Aḍawiyya. ${ }^{2}$

The second method of alteration of meaning, that of tahriff and ta'will, concedes that those who were sent with revelation, such as the Prophet Muhammad, did not intend their respective audiences to believe anything other than what is true in and of itself. ${ }^{13}$ However, what is true in and of itself is precisely that which we come to know through the use of our reason, not necessarily what is suggested by a straightforward reading of the revealed texts. We must then proceed to make various figurative interpretations ( $\left.t a^{3} w i \bar{l} \bar{a} t\right)$ of the texts in accordance with what we believe our reason has established as true. Such interpretations, according to Ibn Taymiyya, typically involve interpreting words in ways that fall outside conventional usage (ikhräj al-lughāt 'an țarīqatihā al$m a^{\prime}$ rüfa) and drawing on far-fetched figures of speech and unlikely metaphors (gharäìb al-majāzāt wa-l-isticārāt). ${ }^{14}$ If the method of wahm and takhyül marks the philosophers' approach to revelation, then that of tahriff and ta'wil represents the choice method of the (later) mutakallimün, who engaged in making ta'wil of the texts on the basis of (putatively) rational considerations.

Whereas both methods of tabdill, or alteration of meaning, presume that the revealed texts possess a true meaning underneath their overt, or literal, sense (a meaning known by the bearer of revelation, the Prophet, and accessible to those possessing the requisite rational capacities), the approach that Ibn Taymiyya refers to as tajhil and tadlill (presumption of ignorance and misguidance) posits a revelation that is partly incomprehensible..$^{15}$ The advocates of this approach concede that certain verses bear meanings other than those most naturally understood from them (tukhālifu madlülahã al-mafhūm minhā) but hold that these true meanings are known to God alone. By consequence, the meanings of such verses are not even known to the Prophet or, by extension, to any of the Companions or Successors, let alone to later generations of Muslim scholars and common people. Those adopting this approach thus practice tafwied by consigning the true meaning of such verses to God, believing this to have been the way of the pious forebears (al-salaf al-șalih). Others maintain that the Prophet himself knew the true meanings of such verses but that he purposely refrained from clarifying them to the community. Rather, he left it for later scholars to convey the true meaning of these verses and to explicate

12 For Ibn Taymiyya's full discussion of the method of wahm and takhyil, see Dar', 1:8-11, along with the corresponding passage in Ibn Sīnā, Aḍawiyya, 97-103.

13 For Ibn Taymiyya's full discussion of the method of tahrīf and ta'wïl, see Dar', 1:12-13.

14 Dar', 1:12, lines 4-5.

15 See Dar', 1:14-17 for Ibn Taymiyya's full discussion of the method of tajhïl and tadlïl. 
them on the basis of rational arguments born of their efforts in the science of non-literal, or figurative, interpretation (that is, $\left.t a^{\prime} w \bar{l} l\right)$. However, given that the Prophet was commissioned to clarify the meaning of revelation to everyone so that they might be rightly guided, his failure to do so would, for Ibn Taymiyya, constitute a positive act of misguidance (hence, "tadlill").

\section{$2 \quad$ The End Result of Figurative Interpretation $\left(t a^{3} w \bar{l} l\right)^{16}$}

I have made frequent mention of the notion of a "conflict" between reason and revelation, specifically with respect to what each allegedly says regarding the nature of God. I have also indicated that the claim of conflict typically takes the form of an assertion that revelation, taken in its obvious sense, seems to affirm of God certain characteristics that reason has judged cannot be properly ascribed to Him as doing so, reason is held to have determined, would result in either (1) violating one or more premises of a rational argument meant to prove the existence of God or the plausibility of authentic revelation or (2) likening God to created things in a manner that would compromise His unique divinity, a phenomenon known as tashbih ("likening" or, more technically, "assimilationism"). The universal rule dictates that any such conflict be decided in favor of reason and that revelation be reinterpreted accordingly. But before taking up the details of Ibn Taymiyya's attempt to refute the universal rule, we must first get a clearer picture of what exactly is at stake for him in the alleged conflict between reason and revelation. What, in other words, did Ibn Taymiyya find so odious about interpreting revelation through $t a^{\prime} w \bar{l} l$ that he felt obliged to write ten volumes in refutation of the universal rule? We can answer this question by considering Ibn Taymiyya's portrayal of the process and the inevitable result of increasingly wanton forms of textual reinterpretation.

One of the main motivations for denying certain of God's attributes-or the divine attributes in general — is, as previously mentioned, to avoid tashbīh, or likening God to created things. ${ }^{17}$ An argument typical of this kind is the one made by the late fourth-/tenth-century Persian Ismāīlī ("Bāținī”) missionary and Neoplatonic philosopher Abū Yáqūb al-Sijistānī (executed ca. 361/971) ${ }^{18}$

\footnotetext{
16 Based on Arguments 30 (Dar', 5:286-288) and 32 (5:320-338).

17 The term "anthropomorphism," by which tashbih is often translated, is too restrictive here as it only implies likening God to human beings, whereas tashbih , as we see in the current example, refers to the likening of God to any created thing-to anything, in short, that is other than God Himself.

18 Alternatively, "al-Sijzī." He is reported to have been executed by the Saffarid governor of
} 
in his work al-Aqälìd al-malakütiyya. ${ }^{19}$ This is the very type of argument by which, in Ibn Taymiyya's assessment, al-Sijistānī and other extreme "negationists" (nufāh) are able to get the better of the various groups that fall along the spectrum from the very slight negationism of the early Ash'aris, through the Mu'tazila, and on to the more comprehensive and systematic negationism of the philosophers. They are able to do this, he explains, because all such groups have concurred with the full-fledged negationists, such as the Bātiniyya, on the legitimacy, in principle, of making figurative interpretation $\left(t a^{3} w \bar{l} l\right)$ of the revealed texts by conceding to them the necessity of negating "what is called tashbih" of any kind whatsoever. ${ }^{20}$ In this manner, any group that affirms any of the divine names or attributes, such as the Living (al-Hayy), the Omniscient (al-'Alìm), the Omnipotent (al-Qadir), and so on, is confuted by the claim that all such predications equally and ultimately entail assimilation (tashbih $)$.

How is this so? The negationist, Ibn Taymiyya explains, contends that the class of "living things" and the class of "existent things" each admit of a twofold logical division into that which is eternal (qadim) and that which is originated in time (muhdath). The fact that the basis of division (mawrid al-taqsim) is shared between the two categories entails a kind of composition (tarkib), which constitutes for the negationist a particularly pernicious form of assimilation, namely, that of corporealism (tajsim). It also entails assimilationism in a more general sense since, according to the argument, if what is eternal (God) and what is temporally originated (the universe) are both said to be "existent," then they are similar to each other (ishtabahā) insofar as they are both subsumed under the nominatum of the term "existence" (ishtaraka fi musammā al-wujūd $)^{21}$ —a fact that inexorably amounts to assimilationism (tashbih $)$. And if it be further held that, say, one of two existing entities (namely, God) is also characterized by the fact of being necessary by virtue of itself (wäjib bi-nafsihi), then this entity shares with the other, non-necessary entity in the nominatum of the term "existence" (musammā al-wujūd) yet is simultaneously distinct from it by virtue of its necessity. Furthermore, that aspect in which it resembles

Sijistan "at an uncertain date (but not long after 361/971)." See Walker, "Abū Ya'qūb alSijistānī," $E I^{3}$ (2007-1), 25.

19 Ibn Taymiyya's presentation and critique of al-Sijistānī's position is found in Argument 32 (specifically at Dar', 5:323, line 5 to 5:324, line 17).

$20 \quad$ "wāfaqūhu 'alā nafy mā yusammā tashbīhan bi-wajh min al-wujūh." Dar', 5:323, lines 7-8.

21 The phrase "mushārakat al-wujūd" is a standard formula for articulating Ibn Sīnā's ontology subsequent to al-Rāzī. See Wisnovsky, "Essence and Existence," 40-48. On al-Rāzī's discussion of mushārakat al-wujūd in his al-Mulakhkhașfíal-hikma, see also Eichner, "The Chapter 'On Existence and Non-existence' of Ibn Kammūna's al-Jadìd fì l-Hikma," 158-163. 
the non-necessary entity (namely, existence) is distinguished from that aspect in which it differs from that entity (namely, its necessity). This leads to the conclusion that the necessary by virtue of itself (al-wäjib bi-nafsihi) is "composed" of both that in which it shares with the other entity (existence) and that which makes it distinct (its unique necessity). But, we are told, reason has determined that whatever is composite (murakkab) in any form is, of necessity, temporally originated (muhdath) rather than eternal (qadim), contingent (mumkin) rather than necessary $(w a \bar{j} j i b)$. The deleterious result of God's essence being "composed" of two "parts," existence and necessity, is said to stem from the fact that such a "composed" entity would be dependent on (lit. "in need of") each of its parts (muftaqir ilā juz'ihi). Now, since a thing's part is necessarily other than the thing itself, the argument continues, it follows that the Necessarily Existent would be dependent on (muftaqir ilä) something other than itself. But that which depends for its existence on something other than itself cannot simultaneously be held to be necessary by virtue of itself ( wäjib bi-nafsihi), enjoying inherent necessity through nothing more than, or other than, its own self. It follows, therefore, that if God is truly God by virtue of His self-necessary, beginninglessly eternal existence, then He must be entirely and utterly simple (basit $t$ ) and in no manner "composed," even if such "composition" be merely a matter of His possessing an entity that is qualified by attributes (and it bears repeating that one of the attributes negated in this argument is the very attribute of existence itself).

In this manner, Ibn Taymiyya concludes, the extreme negationist is able to drag whoever has conceded to him these invalid starting principles (ușūl fäsida) to an outright negation of the Necessarily Existent, whose factual existence (thubüt) is known by rational necessity to every reasonable individual. The Băținī loses in the end, however, for he has brought upon himself the rather serious objection that if, in his desperate attempt to escape assimilationism, he holds that God is, say, neither "existent" nor "living" (as created entities are also said to be existent and living), then he has not escaped assimilationism at all; rather, he has fallen into an even more egregious form of it, for now he has likened God not to any contingent albeit existent thing but to that which is positively non-existent. If he then attempts to skirt this dilemma by claiming that God is neither existent nor non-existent, then he faces the unanswerable objection that "you have established in logic that for any two identical propositions that differ only in affirmation and negation, it necessarily follows that if one of them is true, then the other is false. Thus, if it is true that He exists, then it is false that He does not exist [and vice versa]."22 In accordance with the law 
of the excluded middle, there is no escape from the fact that one or the other of these propositions must be the case. Pushed hopelessly into a corner, the Bāținīs final recourse is to declare, "I do not affirm any of the foregoing propositions: I do not affirm the proposition 'He is existent,' nor the proposition 'He is not existent,' nor the proposition 'He is non-existent,' nor the proposition 'He is not non-existent.'" This, Ibn Taymiyya concludes, is the ultimate position of the atheists (malähida). ${ }^{23}$ By violating the most elementary laws of logic ${ }^{24}$ - here the law of the excluded middle-such a person has fallen into a more serious quandary than the one from which he was attempting to escape. With regard to assimilationism, moreover, he has sought to escape likening God to any existent or non-existent thing by, in the end, likening Him not merely to what is possible but non-existent (such as a unicorn) but, even worse, to what is logically inconceivable and utterly devoid of even purely mental reality (such as a "four-sided triangle"). Not only does that which is "neither existent nor non-existent" have no ontological reality whatsoever, but it is not even logically conceivable and is thus a worse thing to be likened to than something that is at least conceivable even if predicated not to exist.

The foregoing, then, is an example of a denial of some or all of the attributes affirmed of God in revelation on the basis of a rational argument proffered in order to avoid assimilationism (tashbih) at all costs, but this denial ultimately falls apart because it violates the most elementary laws of logic, thus resulting in the worst kind of assimilationism possible - namely, likening God to what is both ontologically impossible and logically inconceivable. Such arguments,

" $P$ does not exist," must necessarily be false, and vice versa. Holding both to be true simultaneously (that is, holding both $p$ and $-p$ ) constitutes a violation of the law of noncontradiction, while holding both to be false simultaneously (that is, holding neither $p$ nor $-p$ ) contradicts the law of the excluded middle.

23 More often than not, Ibn Taymiyya uses the term mulhid (pl. malähida) — which, in modern Arabic usage, normally denotes an atheist—in the sense of "heretic," denoting someone who holds a position considered so fundamentally at odds with basic Islamic teachings as to place him beyond the faith (or very nearly so), even if such a person does not necessarily renounce belief in the existence of God. Given the context in which the term is used here, however, the term "atheist," in the literal sense of denying the very existence of God, is precisely what Ibn Taymiyya seems to have in mind.

24 Here, "logic" is understood not as formal Greek syllogistics, which Ibn Taymiyya rejects, but as constitutive of just that kind of natural, intuitive, straightforward—in other words, "șarīh" — reason that, as we shall discover throughout this study, he champions forcefully. The laws of non-contradiction and the excluded middle, in any case, also lie at the basis of the Greek logic his opponents allegedly prize as the ultimate mechanism of disciplined rational inference. This allows Ibn Taymiyya to best them, as it were, by reducing their position to absurdity on the basis of the very principles they themselves claim to espouse. 
according to Ibn Taymiyya, are typical of those put forth by the various groups of negationists, all of whom (a) concede the theoretical possibility of a bona fide contradiction between reason and (a plain-sense reading of) revelation; (b) concur that, in the event of such a contradiction, reason must be given priority over revelation; and (c) proceed to reinterpret the obvious sense of revelation (that sense which conflicts with their allegedly unimpeachable rational arguments and conclusions) through various degrees of metaphorical interpretation. This process of metaphorical interpretation continues until, eventually, the texts of revelation are eviscerated of any meaning whatsoever and denied all possibility of conveying any factual propositional content about God, the hereafter, or any other of a host of metaphysical, or "unseen" (ghä'ib), realities. This, in short, is what Ibn Taymiyya sees as the inescapable outcome of a consistent and rigorous application of the universal rule - and the $t a^{\prime} w \bar{l} l$ it prescribes - as a means of accommodating revelation to the putative rational objections raised against discrete elements of its overt content.

\section{3}

Specious Rationality and Its Discontents: Reason in a Cul-de-Sac ${ }^{25}$

If such negationism is the result of a consistent application of reason, then we may ask, Is there any alternative other than to interpret metaphorically through ta'wīl, or neutralize through tafwìd, the "problematic" passages of scripture if we seek to safeguard the rational integrity—and, to a large extent, therefore, the plausibility — of revelation? Ibn Taymiyya answers this question about the possibility of an alternative in the affirmative and, in fact, dedicates the bulk of the Dar'ta'ärud's ten volumes to demonstrating that all the alleged rational objections brought to bear against a straightforward reading of revelation (particularly those verses pertaining to God and His attributes) fall apart on purely rational grounds. What is called "reason" gradually breaks down as we move farther away from the true, natural, innate, pure reason ('aql șariḥ) endorsed by revelation and exemplified by the Salaf.

Ibn Taymiyya begins his case with the observation that the principle according to which a person should give precedence to the deliverances of his own rational faculty over the obvious meaning of the revealed texts is not governed by a universally applicable rule (qawl la yandabit ). This is so because kaläm theologians and philosophers (who regularly dispute with one another over what they call "rational knowledge") often make opposite truth claims on the basis

25 Based on Argument 9 (Dar', 1:156-170). 
of identical appeals to rational necessity (darüra) or to the results of discursive inference. For instance, both those who negate (some of) the divine attributes and the divine decree (Ibn Taymiyya singles out the Mutazila and those of the Shīa who followed them), on the one hand, and those who affirm the divine attributes and decree, on the other, claim to do so on the basis of allegedly conclusive rational arguments.

Moreover - and this is a cardinal tenet of Ibn Taymiyya's doctrine on reason and revelation - the farther a school of thought is from the Sunna, ${ }^{26}$ the greater the internal disagreement among its adherents concerning what the dictates of reason are. ${ }^{27}$ This point is essential. For Ibn Taymiyya, reason and revelation coincide in a fundamental sense. As a result, the more a faction moves away from what reason and revelation essentially overlap in affirming, the more it experiences internal dissension, divergences of opinion, and incoherence purely in terms of rational thought, in addition to finding itself at increasingly greater odds with revelation. In other words, either one is fully in line with both pure reason ('aql sarih $)$ and an essentially straightforward reading of authenticated revelation (naql șhịh) or one drifts away both from reason and from revelation simultaneously. In the latter case, one not only ends up contradicting revelation (and seeking to explain it away through an increasingly liberal use of the principle of $\left.t a^{2} w \bar{l} l\right)$ but also falls prey, at the same time, to increasingly intractable rational contradictions, divergences, and improbabilities.

This principle can best be illustrated in the form of the "Taymiyyan pyramid" encountered in the introduction and reproduced on the following page. Truth is that point of unicity, clarity, and certainty (yaqin) at which the testimony of sound reason and that of authentic revelation are fully concordant. According to the pyramid, the Mu'tazila, for example, exhibit greater internal discord than the Ash'arīs and other affirmationists among the mutakallimūn,

26 Ibn Taymiyya's use of the term "Sunna" is perhaps closest to the term "orthodoxy" (lit. "correct belief"). I retain Ibn Taymiyya's original term, however, since it is a more transparent rendering of precisely what "correct belief" is for him and how it is to be determined. For Ibn Taymiyya, as for the mainstream Islamic tradition as a whole, correct belief (as we explore in greater depth in the following chapter) is synonymous with the beliefs and practices of the first three generations (qurūn) of Muslims - that of the Companions (șahāaba), the Successors (täbi üun), and the Successors of the Successors (täbicü al-täbi ìn) —and particularly the first generation comprising the Prophet's own contemporaries. As we shall discover, Ibn Taymiyya's insistence that sound reason and authentic revelation always concur and never contradict necessarily entails that the first generations were in possession both of a uniquely normative — and hence quintessentially "orthodox" — understanding of sacred scripture and of the soundest rational methods used for understanding and reasoning about divine matters.

See Dar', 1:157, lines 4-5. 


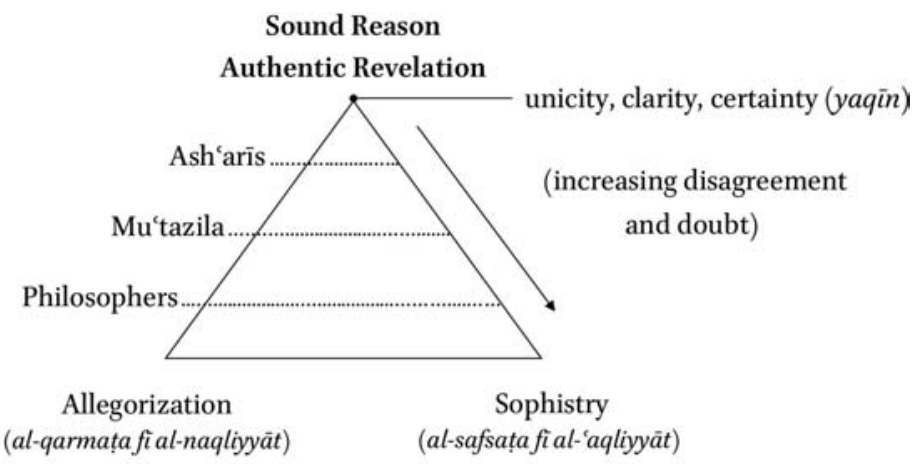

FIGURE 2 The Taymiyyan pyramid

as evidenced by the extent of disagreement between the Mu'tazili school of Basra and that of Baghdad - though adherents of the former, Ibn Taymiyya tells us, are closer to the Sunna (that is, to "orthodoxy") than the latter and are therefore more internally united than their opponents from Baghdad. The Shía evince even greater internal discord than the Mu'tazila since they are even farther removed from Sunna-based orthodoxy. As for the philosophers, Ibn Taymiyya remarks, it is almost impossible to find anything upon which they collectively agree. In point of fact, their internal divergences are greater than those that separate the distinct religious communities of Muslims, Jews, and Christians. ${ }^{28}$ Indeed, he argues, the philosophers' differences with regard to astronomy alone - which is a computational, mathematical subject that figures among the most objective and accurate of their sciences - are greater than the differences among any of the various sects of Muslims. As for metaphysics, the leading philosophers themselves concede their inability to reach any kind of certitude regarding it whatsoever. Rather, their discourse on metaphysical matters amounts to no more than weighing various probabilities and hazarding judgements of likelihood and probability. ${ }^{29}$

28 Here, Ibn Taymiyya is apparently not referring to the internal divergences within each confessional community; rather, he is saying that the differences that separate the three communities are still fewer than those that divide the philosophers. In other words, Muslims, Jews, and Christians, notwithstanding the (sometimes fundamental) differences that separate them, are nevertheless in agreement with one another on a considerably greater number of issues than are the philosophers—all of whom claim, despite their wild divergences of opinion, to have arrived at their various doctrines through pure reason on the basis of rationally demonstrable arguments and unimpeachable proofs.

$29 D a r^{\prime}, 1: 157$, line 5 to 1:159, line 5. Ibn Taymiyya refers his reader to a number of sources to support his point regarding the disarray of the philosophers. These include al-Ash'ari's

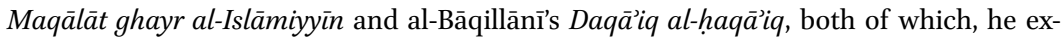


To underline the specious nature of much of kaläm discourse, Ibn Taymiyya appeals to several of the major rationalists (nuzzār) themselves who testify to the futility of their life-long efforts to attain theological certainty through the practice of dialectical theology. The following two lines by al-Shahrastānī, for instance, emphasize how such thinkers often reached only a state of confusion and perplexity:

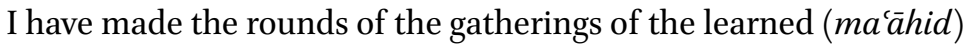

And cast my eyes upon the haunts of erudition (macalim);

Yet never did I see but men perplexed, with their chins in their hands

Or gnashing their teeth in regret. ${ }^{30}$

Ibn Taymiyya also cites three lines of poetry to a similar effect from a work of al-Rāzī, which Ibn Taymiyya refers to as Aqsām al-ladhdhāt. ${ }^{31}$ This passage reads: ${ }^{32}$

Entanglement, the acme of minds' pursuit,

Most human endeavour is but straying;

Our souls are estranged from our bodies,

plains, contain many times more in the way of disputes and differences among the philosophers than what al-Shahrastānī (in his Milal) and others have mentioned. AlBāqillān̄’s Daqā̇iq, unfortunately, is lost. (See editor's note at Dar', 1:6, n. 3.)

$30 \quad$ "la-qad țuftu fì tilka l-ma'āhidi kullihā, wa-sayyartu țarfí bayna tilka l-måălimi / fa-lam ara illā wādián kaffa hạ̄irin, 'alā dhaqanin aw qārian sinna nādimi." Dar', 1:159, lines 1011. Muhammad Rashād Sālim (at Dar', 1:159, n. 2) also cites a two-line response to alShahrastānī from the latter-day Yemeni scholar Muhammad b. Ismācīl b. al-Amīr al-Ṣan‘ānī (d. 1182/1768), who retorted, "láallaka ahmaltal-țawāfa bi-ma'hadi, l-Rasūliwa-man lāqāhu min kulli 'ālimi / fa-mā ḥāra man yuhdā bi-hadyi Muḥammadin, wa-lasta tarāhu qāri'an sinna nādimi":

Perhaps your rounds have missed the learned circle ( $\mathrm{machad}$ ) of the Prophet, And every man of knowledge ('âlim) who encountered him;

For he who is led by the guidance of Muhammad is never perplexed,

Nor ever found gnashing his teeth in regret.

31 See Dar', 1:159, lines 12-13. The more common name for this treatise is Dhamm al-ladhdhät (or Dhamm ladhdhāt al-dunyā), a critical edition of which can be found in Shihadeh, Teleological Ethics, 212-265 (see pp. 205-209 for a discussion of the manuscript basis used for the edition), preceded by an extensive analysis and commentary at pp. $155^{-203}$. Shihadeh (p. 209) cites several alternative names by which the treatise is sometimes known and attributes the title Aqsām al-ladhdhāt solely to Ibn Taymiyya and his student Ibn Qayyim al-Jawziyya. Sālim remarks that Ibn Taymiyya cites these lines from al-Rāzī on numerous occasions throughout his writings. See Dar', 1:16o, n. 4.

As translated by Shihadeh (Teleological Ethics, 187). 
The yield of our world, but harms and bane;

All we've gained from a lifelong research,

Is but collecting quotations and sayings. ${ }^{33}$

Ibn Taymiyya continues citing from the same work, where al-Rāzì states, in a manner reminiscent of al-Ghazālī in al-Munqidh min al-daläl, that he has contemplated the methods of both the philosophers and the mutakallimün and has found neither to be of any ultimate benefit. Rather, he has found that the most reliable way is that of the Qurān, which affirms the divine attributes in verses such as "The Most Merciful has settled upon the throne" (Q. T⿱a Hā 20:5) and "To Him ascends the goodly word and He raises up righteous deeds" (Q. Fătir 35:10). Yet it also contains verses that negate any notion of commensurability or essential comparability between God and creation, such as "There is none like unto Him" (Q. al-Shūrā 42:11), "They encompass Him not in knowledge" (Q. T⿱a $H \bar{a}$ 20:110), and "Have you knowledge of anything like unto Him?" (Q. Maryam 19:65). Ibn Taymiyya concludes by quoting al-Rāzī's statement that "whoever experiences what I have experienced will come to know what I have come to know." ${ }^{34}$

33 "nihāyatu iqdāmi l-'uqūli 'iqālu, wa-aktharu sa'yi l-āalamina ḍalālu / wa-arwāḥunā fì waḥshatin min jusūminā, wa-ḥāṣilu dunyānā adhan wa-wabālu /wa-lam nastafid min baḥthinā țūla 'umrinā, siwā an jama'nā fìhi qüla wa-qālū." Dar', 1:16o, lines 5-7. This passage as it appears in al-Rāzī (see Shihadeh, Teleological Ethics, 262) contains two additional lines: "wa-kam ra'aynā min rijālin wa-dawlatin, fa-bādū jamīan musrīina wa-zälū / wa-kam min jibālin qad 'alat shurufātihā, rijālunfa-zālūwa-l-jibālujibālu." Shihadeh (TeleologicalEthics, 187) translates:

Many a man and dynasty we have seen,

That all quickly perished and expired;

Many a mountaintop was surmounted,

By men, who perished, yet the mountains remain.

34 Dar', 1:16o, lines 12-13. For this quotation, see al-Dhahabī, Siyar, 21:501. In his Tārīkh alIslām, 43:218-219, al-Dhahabī quotes al-Rāzī as saying, "I found the best (aṣlaḥ) and most correct (așwab) way to be that of the Qur'ān, which entails 'tark al-rabb' [?], then refraining from going too deep (tarkal-ta'ammuq), then glorifying [God] greatly without delving into details." Tāj al-Dīn al-Subkī (d. 771/1370) transmits a quotation of similar import in Ṭabaqāt al-Shäfíyya al-kubrā, 8:91. Tony Street, however, argues that when al-Rāzī's wașiyya is read in its entirety, it is "hardly a repentance for having used kaläm" but rather a question of alRāzī "simply recognizing his own scholarly limitations." Street, "Concerning the Life and Works," 4-5. Street goes on to identify none other than Ibn Taymiyya's (decontextualized) paraphrase of al-Rāzīs wașiyya as giving rise to the claim, from the late eighth/fourteenth century onward, that al-Rāzī had "repented" from kalām on his deathbed. Shihadeh, in contrast to Street, affirms that al-Rāzī not only recognized his own scholarly limitations but also found himself, towards the end of his life, deeply pessimistic about whether reason could lead to certitude. See Shihadeh, Teleological Ethics, 155-203, esp. 181ff. 
Ibn Taymiyya also cites nine lines of similar import from Ibn Abī al-Ḥadīd (d. 656/1258), "one of the foremost Shīì thinkers with Mu'tazilī and philosophical leanings." ${ }^{35} \mathrm{He}$ also points out that the illustrious latter-day Ash'arī theologian and legal scholar Sayf al-Dīn al-Āmidī (d. 631/1233), in most of his books, suspends judgement on many of the central issues of theology, declaring the arguments of various sects spurious but ultimately remaining perplexed and unable to take a position himself. ${ }^{36}$ Similarly, the celebrated seventh-/thirteenth-century logician and judge of Persian origin, Afḍal al-Dīn al-Khūnajī (d. 646/1248), best known for his logical treatise Kashf al-asrār 'an ghawämid al-afkār, was reported to have said on his deathbed, "I die having learned nothing but that the contingent is dependent on the impossible (almumkin muftaqir ilā al-mumtani'), yet dependence (iftiqār) is a negative property; thus, I die having learned nothing at all."37

Indeed, Ibn Taymiyya remarks, even al-Ghazālī, despite his tremendous intelligence and pious devotion, his knowledge of discursive theology and philosophy, and his traveling the Sufi path of asceticism and spiritual discipline, nonetheless ended up suspending judgement on such matters and referred, in the final analysis, to the method of private intuition and spiritual unveiling (kashf). Nevertheless, he reports, al-Ghazāli returned to the way of the people of hadith at the end of his life and, upon his death, was occupied with the study of al-Bukhārî's Șa hị collection of authentic prophetic reports. ${ }^{38}$ Another result of the futility of the rational methods used in discursive theology, in Ibn Taymiyya's view, is that al-Ghazāli refuted the methods and arguments of the philosophers but did not affirm any particular method of his own. Rather, as al-Ghazālī admits in his famous work Tahāfut al-falāsifa,

I hold them to the [full and undesirable] consequences of their doctrine (ulzimuhum) by arguing at times from the position of the Mu'tazila, at times from the position of the Karrāmiyya, and at other times from the position of those who suspend judgement (al-wäqifa), yet I refrain from defending any particular position myself. ${ }^{39}$

36 Dar', 1:162, lines 3-4.

37 Dar', 1:162, lines 4-7 (also cited in Ibn Taymiyya, Radd, 114). This incident is reported by 'Afîf al-Dīn al-Tilimsānī in Sharh Mawāaif al-Niffarī, 171. (See index of Arabic passages.)

38 Dar', 1:162, lines 8-11. We have heard this claim before (at p. 112, n. 140 above). See Griffel, Al-Ghazālı’'s Philosophical Theology, 56-57.

39 Dar', 1:163; al-Ghazālī, Tahāfut, 82-83. (See index of Arabic passages.) Ibn Taymiyya's critique of al-Ghazālī here is perhaps unjustified, at least with respect to the Tahäfut, as alGhazālī himself explicitly states that this work was meant to be purely deconstructive and that he had no intention of establishing or defending in it a systematic doctrine of his own. 
Ibn Taymiyya also informs us that a group of leading mutakallimūn used to speak of the "equivalence of proofs" (takäfu' al-adilla), claiming that the various arguments advanced to prove a particular point cancelled one another out, making it impossible to determine, on rational grounds, truth from falsehood with respect to the given question. Ibn Taymiyya relates that it was reported to him that a certain Ibn Wāșil al-Hamawi (d. 697/1298), who had studied with the foremost authority of his time in the fields of discursive theology and philosophy, used to say, "I lie in bed at night, pull the covers over my eyes, and weigh the arguments of this group and of that group until morning comes with neither position having proved to be the stronger one." 40

Ibn Taymiyya contrasts the drastic agnostic pessimism expressed in the numerous quotations above with what he describes as the calm assuredness of those who know and who cling resolutely to the "original, pristine, orthodox, scripturally revealed prophetic method." ${ }^{41}$ Such men are thoroughly familiar both with this method and with the doctrines that are said to be in contradiction with revelation, such as the claim of the createdness of the Qurann or the purely abstract or symbolic nature of the divine attributes. Therefore, they can easily recognize the invalidity of such doctrines by virtue of the deliverances of what Ibn Taymiyya calls "pure natural reason" (al-maiqūl al-șarịh), which is always found to be in full conformity with what is affirmed by authentic revelation (al-manqūl al-sahīh). However, those who delve into the elements of philosophy and discursive theology that are said to contradict revelation, but without possessing full knowledge of the contents and the consequents (lawazim) of the revealed texts or of the doctrines alleged to be at odds with them, are unable to arrive at any certain knowledge with confidence. Instead, they end up in confusion and perplexity. The most preeminent of them are even at a loss to furnish conclusive arguments for the existence of the Creator Himself, a topic of central concern to Ibn Taymiyya in the Dar' and one that merits a study of its own. Some, he says, end up perplexed, like al-Rāzī, while others, like al-Āmidī, are forced to suspend judgement on the matter. Indeed, such thinkers often mention numerous positions held by different schools, claiming that truth lies in one or the other of them though they cannot necessarily determine which one. Yet all the various positions mentioned, Ibn Taymiyya declares confidently, can, in fact, be shown on the basis of pure natural reason (bi-l-ma'qūl al-șarịh) to be false and without rational foundation. ${ }^{42}$

\footnotetext{
$40 \quad$ Dar', 1:165, lines 3-4.

41 "al-țariqa al-nabawiyya al-sunniyya al-salafiyya al-Muhammadiyya al-shariyya." Dar', 1:164, line 1.

42 See Dar', $^{\prime} 1: 164$, passim.
} 
If, as Ibn Taymiyya sees it, the rational processes advocated by the philosophers and the mutakallimün lead to such an abusive "interpretation" of scripture and, at the same time, to a rational dead end in which reason itself breaks down, then what is the solution? This is the question to which Ibn Taymiyya has dedicated the entirety of the Dar'ta'a arud and to which we turn our attention for the remainder of this chapter. Ibn Taymiyya's project in the Dar', at its most essential, consists in undermining and refuting the universal rule itself, along with the premises and assumptions on which it is based, since he considers this rule the primary cause of the intellectual and religious disarray he inherited at the turn of the eighth/fourteenth century. For Ibn Taymiyya, the project of refuting the universal rule is imperative not only to salvage the integrity of revelation but to rescue reason as well since both were dangerously compromised, in his view (and as illustrated by the Taymiyyan pyramid diagrammed above, p. 143), primarily by a faulty and abusive use of the rational faculty.

To refute the universal rule, Ibn Taymiyya puts forth around thirty-eight discrete "arguments" (wujūh, sing. wajh; lit. "aspects" or "viewpoints") ${ }^{43}$-located primarily in volumes 1 and 5 of the Dar' - to demonstrate why the rule, as it came to be formulated, is logically unsound and, therefore, theoretically baseless. As is typical of Ibn Taymiyya's writings, a number of these arguments overlap with one another, some seemingly forming an expanded or summarized version of others. Furthermore, the arguments as Ibn Taymiyya presents them do not follow any specific logical order but rather are given one after the other as so many discrete objections to the universal rule. For our purposes here, instead of simply listing the arguments in the order in which Ibn Taymiyya presents them, I have grouped them by theme and argument. In each of the sections that follow, I paraphrase a coterie of arguments that share a unifying theme or that seem intended by their author to accomplish a common objective. The first three sections below (sections 5,6 , and 7 ) cover specific criticisms that, collectively, aim to shift the inherited paradigm of reason and revela-

43 Tariq Jaffer discusses al-Rāzì's use of the wajh (translated as "viewpoint" or "argument"), which, in addition to the mas'ala (which he renders as "question" or "point of investigation"), lies at the center of his dialectical method-a method that the philologist, littérateur, and biographer Șalāh al-Dīn Khalīl b. Aybak al-Ṣafadī (d. 764/1363) characterized as unprecedented. Jaffer explains that al-Rāzī used the wajh both to corroborate and to critique philosophical arguments and as a vehicle to record and resolve the shubuhät (or shubah; sing. shubha) — that is, the objections or counter-arguments—raised against a given position. See Jaffer, Rāzi, 27-29. On the "dialectical turn" that occurred in the sixth/twelfth century, see Griffel, "Between al-Ghazālī and Abū l-Barakāt al-Baghdādī.” 
tion in three distinct ways. In the subsequent section (section 8), I present the gist of a number of more generic arguments Ibn Taymiyya levels against the overall coherence and logical validity of the universal rule, and in a final section (section 9), I showcase some of the purely revelation-based arguments he deploys against the universal rule, arguments that are meant to complement and support the primary rational arguments against it that form the backbone of the Dar' ta'ärud. The presentation in sections 5 through 9 below, together with sections 2 and 3 above, accounts comprehensively for these thirty-eight arguments. ${ }^{44}$ The remaining six of the forty-four arguments (wujüh) listed in the Dar, 45 it turns out, are not "arguments" at all but extended disquisitions (some of which run on for several hundred pages) concerning highly complex substantive philosophical and theological problems. In chapters 4 through 6 , which deal with the more specific theological and philosophical issues Ibn Taymiyya takes up throughout the Dar', I introduce and analyze select portions of these six arguments, in addition to other relevant sections of the thirty-eight arguments presented globally in the remainder of the current chapter.

\section{On Reason Grounding Our Knowledge of Revelation ${ }^{46}$}

Ibn Taymiyya endeavors to undermine the universal rule's main premise, namely, that giving precedence to revelation over reason would amount to a rejection of the very thing that grounds revelation (that is, reason), which would fatally undercut revelation itself. "Grounding" here implies that reason is the basis on which our knowledge of the truth and validity of revelation rests; that is, reason grounds revelation not ontologically but epistemologically.

44 Relevant sections of Arguments 17 and 18 are treated in subsequent chapters.

45 Namely, Arguments 17 (Dar', 1:208-279), 18 (1:280-320), 19 (1:320-406?), 20 (5:3-203), 43 (6:3-353 and 7:3-140?), and 44 (7:141-464?). [N.в.: It is not clear whether Argument 19 ends at Dar', 1:406 or continues on to volume 2, nor is it clear whether Argument 43 stops at a point before Dar', $^{2}: 140$. Similarly, it is unclear whether Argument 44 is meant to stop at the end of volume 7 or continues on to volume 8. These three wujüh are among the "arguments" that, as explained in the introduction (p. 14, n. 38 above), are not discrete arguments against the universal rule at all but rather extended discussions and refutations covering numerous topics and authors. Since each of these discussions carries on for sometimes hundreds of pages, it is difficult to determine exactly where the "argument" in question is meant to end.]

46 The question of the manner in which revelation is grounded in reason is taken up primarily in Arguments 3 (Dar', 1:87-133), 24 (5:214-216), and 29 (5:268-286). 
Ibn Taymiyya begins by challenging the philosophers' and theologians' notion of precisely what is implied by the claim that our knowledge of revelation is grounded in reason. "We do not concede," he tells us, "that if precedence be given to revelation, this would amount to impugning the very thing that grounds it, namely, reason." ${ }^{\prime 7}$ This is so because if it is the knowledge we acquire through reason that constitutes the epistemological grounding upon which our knowledge of the truth and validity of revelation rests, it is nonetheless true that not everything known (or thought to be known) through reason is part of the rational knowledge that authenticates revelation. The various objects of knowledge apprehended through reason are innumerable, and knowledge of the validity and truth of revelation is contingent, at most, upon that by which the veracity of the Prophet Muhammad and his prophetic mission can be determined. Relevant (rational) knowledge here would be, for example, proof of the existence of God, His vindication of the truthfulness of the Prophet through miracles, and the like. Ibn Taymiyya explains that the principal error of those who call for adherence to the universal rule is that they place all forms of rationally grounded knowledge in one category with respect to validity and invalidity. In reality, however, our ability to form a positive rational judgement on the validity of revelation does not require that all conclusions we may reach through our reason be true. Rather, it requires the validity only of those specific rational conclusions that relate to the truth of revelation (as a whole), not the validity of those rational conclusions that contradict or are incompatible with (certain of the discrete assertions of) revelation. ${ }^{48}$

It is significant that Ibn Taymiyya explicitly classifies knowledge of the existence of God, the reality of prophecy, and the possibility of miracles as propositions subject to verification through the use of reason. This is tantamount to an acknowledgement that revelation is, in fact, fundamentally grounded in reason, for it is by reason alone that we can test and confirm the most basic claims of revelation. This finding, recently corroborated by Frank Griffel, ${ }^{49}$ thus corrects Nicholas Heer's contention that "as a Hanbalite traditionalist Ibn Taymiyah held firmly to the position that scripture was in no way dependent on rational arguments, either for the establishment of its truth or for an explanation of its meaning.".50 Heer seems to have missed the fact that, according to

$47 \quad$ Dar', $^{3}: 87$, lines 12-13.

48 "wa-ma'lūm anna al-sam' innamā yastalzimu șị̣hat ba'dihā al-mulāzim lahu lā șiḥhat alba'd al-munāfi lahu." Dar', 1:91, lines 4-5.

49 See Griffel, "Ibn Taymiyya and His Ash'arite Opponents," 36-37.

$5^{\circ}$ Heer, "Priority of Reason," 191-192. In an earlier passage, Heer remarks, "Scripture, [Ibn Taymiyya] claims, does not have to be proven true through the use of reason, as the theolo- 
Ibn Taymiyya, revelation does indeed rely on arguments-rational arguments - to support its principal doctrines. In fact, Ibn Taymiyya makes much of the fact that revelation includes and advances rational arguments, trying to wrest the rational high ground from the philosophers and the mutakallimün and to reclaim it for revelation. It would be desirable to examine in detail the rational arguments Ibn Taymiyya gives for the existence of God and the possibility of miracles (as against those of the theologians and philosophers) in order to define precisely what he means when he claims that reason is capable of establishing such matters in a manner conclusive enough to lend the fundamental claims of scripture a baseline of rational plausibility. However, an in-depth analysis of such arguments lies beyond the scope of this study.

Ibn Taymiyya entertains a possible objection to his argument that the truth of revelation depends not on the inerrancy of the rational faculty per se but only on the accuracy of its specific judgements regarding the authenticity of revelation. According to this objection, one need not prioritize all rational conclusions over revelation but only those by which one has determined the validity of revelation. To this Ibn Taymiyya responds that with respect to the so-called 'aqliyyāt (or rational conclusions) said to contradict revelation, he will demonstrate that none of them, in fact, form part of that rational knowledge upon which our knowledge of the authenticity of revelation is contingent. Therefore, every product of reason (that is, every ma'qūl) that is said to oppose revelation is, in fact, extrinsic to the set of (valid) rational judgements that ground (our knowledge of) revelation. From this Ibn Taymiyya concludes that challenging any of these particular judgements of reason does not, in fact, undermine the foundations of revelation.

This conclusion should be little cause for controversy since, Ibn Taymiyya tells us, most people agree that knowledge of the existence of God and the veracity of the Prophet-in other words, that rational knowledge upon which our knowledge of the authenticity of revelation does depend-is not contingent upon those elements of rationally derived knowledge that some claim to contradict revelation. For example, he tells us, those who have formulated and established (al-wādieüna li) the universal rule, such as al-Ghazālī, al-Rāzī, and others, concede that knowledge of the Prophet's veracity is not contingent upon any putative rational conclusions that are at odds with revelation. In fact, a great number of them-including al-Ghazālī himself, in addition to al-Shahrastānī, al-Rāghib al-Aṣfahānī (d. ca. 502/1108), and others-hold that

gians assert, because it itself contains all the arguments necessary to support its principal doctrines" (Heer, 188). 
knowledge of the existence of God is both innate and necessary ( fitrī darūrū $).{ }^{51}$ In addition, Ibn Taymiyya maintains, revelation itself is replete with rational arguments for the existence and omnipotence of the Creator and His corroboration (through miracles and signs) of the veracity of His Messenger. What revelation affirms of these matters does not contradict, but rather accords with (yuwāfiq), the rational foundations on the basis of which we come to know the authenticity of revelation. Furthermore, according to Ibn Taymiyya, revelation provides far more numerous - and far more evincive - rational arguments for such matters than we find in the books of the rationalists themselves. Even the majority of those who maintain that knowledge of the Creator comes about only through rational inference (nazar) - as opposed to arising instinctively (bi-l-fitra) - concede, critically, that of the various inferential methods available for arriving at knowledge of the truthfulness of the Prophet, there indeed exist some that do not contradict anything affirmed in the revealed texts. In fact, al-Rāzì himself, Ibn Taymiyya informs us, is one of those who concur on this point, as evidenced by a passage in Nihāyat al- 'uqūl in which al-Rāzī concludes:

It has been established that knowledge of the principles $(u s ̦ \bar{u} l)$ upon the validity of which [our knowledge of the authenticity of] the messengership of Muhammad (may God bless him and grant him peace) depends is patent and evident knowledge ('ilm jalı za ăhir); these principles have been discussed at length only to remove the doubts raised by those who would declare them false (al-mubțilün) ... [Otherwise,] it is firmly established that the foundations of Islam are patent and clear and, furthermore, that the proofs establishing them are mentioned in a comprehensive manner ('alāal-istiqșa ${ }^{\prime}$ ) in the Book of God [and are] free of anything erroneously imagined to oppose them. ${ }^{52}$

In establishing the foregoing point, Ibn Taymiyya reverses the universal rule to show that the opposite principle-namely, prioritizing revelation over reason in case of conflict - can be argued and defended in a precisely analogous manner. ${ }^{53}$ This leads to the conclusion that if we cannot put reason above revelation or revelation above reason, then the truth (which is intrinsically coherent) must lie in the fact that these two sources of knowledge can

$5^{1} \quad$ See, e.g., al-Shahrastānī, Nihāyat al-iqdām, 118-119.

$5^{2}$ Dar', 1:96; al-Rāzī, Nihāyat al-'uqūl, 4:29o-291. (See index of Arabic passages.)

53 For this point overall, see Argument 6 at Dar $^{\prime}, 1: 138-144$. 
never truly be in contradiction - the precise point Ibn Taymiyya is concerned to prove in the Dar'ta'ärud. The opposite rule to the theologians' qänün al-ta'wīl would state:

If reason and revelation contradict each other, then revelation must be given priority over reason since reason has adjudged revelation veracious in everything it contains, whereas revelation has not judged reason to be correct in all its various conclusions, nor is our knowledge of the authenticity of revelation contingent on (mawqū 'ala $)$ all the separate conclusions at which reason may have arrived. ${ }^{54}$

This position, says Ibn Taymiyya, is better advised (awjah) than the previous position (that of granting blanket priority to reason over revelation) since reason indicates the truth of revelation in a general and unconditional manner (daläla ämma muțlaqa). This is like the hypothetical case of Layman $A$ (let us call him Zayd) and Layman $B$ (let us call him 'Amr). Zayd knows a particular man to be a reliable mufti and refers 'Amr to him for legal advice. Now, if Zayd then differs with the mufti's judgement in a particular legal matter, it would nevertheless be incumbent on 'Amr to adhere to the mufti's opinion over that of Zayd, despite the fact that Zayd is the source of 'Amr's knowledge that the mufti was reliable to begin with. This is so because Zayd, by producing convincing evidence of the mufti's competence, has established a general obligation to follow the mufti's judgement on particular legal matters over anyone else's (including that of Zayd himself). 'Amr's acceptance of Zayd's evidence that the mufti is competent does not obligate him to accept Zayd's opinion in all matters, nor, conversely, does Zayd's error in legal judgement (represented by his disagreement with the mufti on a particular point of law) entail that he was incorrect in his assertion of the mufti's professional competence. This is true because Zayd's ability to determine accurately that the mufti is indeed competent in issuing legal responsa does not require that Zayd possess this same ability himself: one may, after all, confidently recommend a doctor to a friend without oneself possessing any detailed knowledge of medicine. Furthermore, 'Amr's obligation to accept the mufti's judgement holds even though the mufti is fallible and it is therefore conceivable for him to err in a given legal opinion. How much more obvious and stringent, then, is the obligation for us to accept the truth of what we have been informed of through the Prophet, who is known by reason (if he is truly a prophet) to be infallible in matters of conveying revelation from God? It follows from this, Ibn Taymiyya concludes, that the principle by which all agree that 'Amr is obliged to hold the opinion of the mufti in higher esteem than that

Dar', 1:138, lines 1-3. (See index of Arabic passages.) 
of Zayd on discrete legal points is even more applicable with regard to granting priority to the words of an infallible prophet over the conclusions of one's own decidedly fallible reasoning. 55

This is especially true, Ibn Taymiyya explains, given that the disparity between a prophet, on the one hand, and the most intelligent and knowledgeable of ordinary men, on the other, is manifestly greater than the disparity between, for instance, a master craftsman and a beginning apprentice. In fact, the difference involved is no less than categorical since, theoretically, any ordinary man could, by dint of sustained personal effort, attain mastery of a given field, whereas prophethood cannot be attained through personal striving but rather is bestowed by God upon those whom He has elected to the prophetic office. ${ }^{56}$ Similarly, we trust and follow the prescriptions of physicians-regardless of the pain and inconvenience often occasioned by the remedies they prescribe and in spite of our knowledge that they may err and that their putative cures may even lead to our death - even when, at times, our own intuitions concerning the restoration of our health may be at odds with the doctor's orders. So what, then, of cases in which our mere conjecture"rational" or otherwise-conflicts with what we know to have been revealed on the tongue of a prophet, whom we know through rational arguments to be infallible in his transmission of revelation to us from God? ${ }^{57}$

In addition to the foregoing rational arguments, Ibn Taymiyya also casts the issue in terms of a hypothetical that renders the religious implications of the matter immediately transparent. Imagine, he bids us, that someone had come to the Prophet during his lifetime and said to him:

This Qur'ān, or Wisdom (al-hikma), that you have transmitted to us contains many elements that contradict what we know through our reason, yet we have only come to know your truthfulness through our reason as well. Thus, if we accept everything of which you inform us, despite the fact that reason contradicts some of it, then that would undermine the very thing — namely, reason — by which we have come to affirm your veracity.

55 Dar', 1:138, line 4 to 1:139, line 5.

56 See Dar', $^{\prime}$ 1:140, line 11 to 1:141, line 3. Ibn Taymiyya is citing here the orthodox theological position regarding the purely God-given, non-acquired (ghayr muktasab) nature of the prophetic office, as opposed to the philosophers' interpretation of prophethood as an essentially natural faculty analogous to the bursts of inspiration from beyond that may result from the personal spiritual efforts of a practicing sage or mystic. For more on various conceptions of prophethood in Islam, see Rahman, Prophecy in Islam.

Dar', 1:141, lines 10-16. 
We therefore hold to be true the positions derived from our reason that stand in contradiction with the plain meaning of what you have brought, from which [meaning] we turn away, gaining therefrom neither guidance nor knowledge. ${ }^{58}$

We know as a necessary fact of the Islamic religion (na lamu bi-l-idțirār min dīn al-Islām), ${ }^{59}$ says Ibn Taymiyya, that the Prophet would not have accepted this stance as constituting authentic belief in revelation. Indeed, if this were admissible, then it would be possible for anyone to object to any particular element of revelation. This is so because people differ in their intellectual capacities, there are numerous potential objections that could be raised against any given proposition, and Satan continually insinuates doubt and misgivings into men's hearts.

In summary, Ibn Taymiyya endeavors, through the set of arguments presented above, to undermine the universal rule's main premise, namely, that if precedence be given to revelation over reason, then this would amount to a rejection of the very thing that grounds revelation (namely, reason) and thereby fatally undercut revelation itself. Ibn Taymiyya challenges the philosophers' and theologians' notion of what it means for our knowledge of revelation to be grounded in reason by arguing, in essence, that what we call "reason" does not, as many imagine, constitute one undifferentiated category such that impugning any of the various conclusions reason might reach would amount to undermining all of them. Rather, he contends, there are innumerable discrete conclusions we might reach through the rational faculty, and our knowledge of the validity of revelation is contingent, at most, only upon those discrete elements of rational judgement through which, for instance, we can ascertain the veracity of the Prophet Muhammad and the authenticity of his prophetic mission. If this be the case, then imprecating other conclusions of reasonsuch as those that contradict certain discrete assertions of revelation-would not, as most theologians and philosophers held, automatically compromise the rational faculty itself and each one of its sundry conclusions, not least the rational basis by virtue of which we may ascertain the authenticity of revelation.

$58 \quad$ Dar', 5:214, line 6 to 5:215, line 3. (See index of Arabic passages.)

$59 D_{a r}, 5: 214$, line 16. For the point made in this paragraph in general, see Dar', 5:214-216, which comprises the entirety of Argument 24. 
Ibn Taymiyya's refutation of the universal rule consists in showing the falseness of its premises. The rule, as enumerated in section 1 above, is based on the following three premises:

1. There exists an actual contradiction between reason and revelation.

2. The possible options for dealing with the alleged contradiction are limited to the following four: (a) accepting both contradictory statements simultaneously, (b) rejecting both simultaneously, (c) prioritizing revelation over reason, or (d) prioritizing reason over revelation.

3. The first three alternatives in premise 2 are invalid. Therefore ...

Conclusion: It is necessary to accept the fourth alternative, namely, giving priority to reason over revelation and reinterpreting revelation accordingly.

Ibn Taymiyya rejects all three premises as invalid. His attempt to prove the falsity of premise 1 is the mission of the entire Dar'ta'arrud and is treated in greater depth in the course of subsequent chapters. Here, however, I discuss his concentration on undermining premise 2 , which he does by refusing to concede the four-fold division of the premise. Instead, he holds, a given rational indicant may take priority in some instances, while the scriptural indicant may take precedence in others. How is this so? Ibn Taymiyya explains: If two indicants contradict each other-irrespective of whether they are both scriptural, both rational, or one of them scriptural and the other rational — then it must be the case that they are both conclusive (qat $\bar{\imath}$ ), that they are both inconclusive (zannī), or that one is conclusive and the other inconclusive.

If both are conclusive, then it is theoretically impossible that they should contradict each other, regardless of whether they are both rational, both scriptural, or one rational and one scriptural. Therefore, it follows that if two conclusive indicants were contradictory or if one of them contradicted what is indicated or established by the other, then this would entail a violation of the law of non-contradiction, which is impossible. Rather, for any two indicants that are thought to be conclusive and that also seem to contradict each other, it must be the case either that one of them is not, in fact, conclusive or that the respective propositions they establish do not, upon closer scrutiny, stand in actual contradiction.

6o Ibn Taymiyya's development and discussion of the dichotomy "knowledge vs. conjecture" is located primarily in Arguments 1 ( Dar' $\left.^{\prime}, 1: 86-87\right), 2$ (1:87), 4 (1:134-137), and 5 (1:137). (For the material presented here [p. 156], however, see Dar', 1:78, line 10 to 1:79, line 11.) 

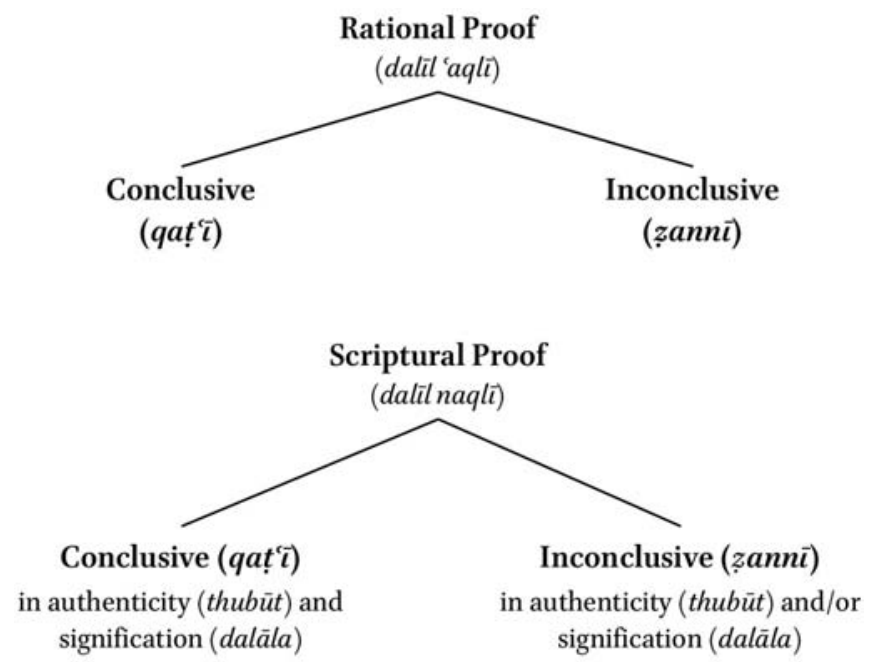

FIGURE 3 Both rational and scriptural proofs admit of being conclusive or inconclusive

Furthermore, Ibn Taymiyya argues, if one of the indicants is conclusive to the exclusion of the other, then all rational persons ('uqalä') agree by consensus that priority must be given to the conclusive indicant irrespective of whether it comes from revelation or from reason, since probability can never override certainty. If both indicants are inconclusive $($ zanni $)$, then one must investi-

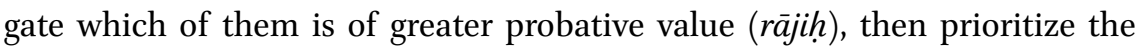
stronger one over the weaker one by virtue of its superior evidentiary valueirrespective, once again, of its epistemological origin (whether scriptural or rational). ${ }^{61}$ Consequently, it is false to claim that one must give absolute precedence either to the scriptural or to the rational indicant on pain of violating the law of non-contradiction or the law of the excluded middle, for indeed there exists an alternative to the four options mentioned in premise 2 above: namely, that precedence be given to whichever of the two indicants is conclusive or, barring conclusiveness, to whichever enjoys greater probative weight, regardless of whether it is scriptural or rational. This last procedure, Ibn Taymiyya asserts, is the correct one. ${ }^{6}$

The only possible objection to the foregoing rule, Ibn Taymiyya explains, would be to maintain that a scriptural indicant can never be conclusive. AlRāzī, it turns out, held just such a position. According to him, it is impossible

61 Dar', 1:79, lines 12-15.

62 See Dar $^{3}, 1: 87$, lines 5-11 (comprising all of Argument 2) for a statement of this point. 
TABLE 4 Predominance (tarjịh) chart for scriptural and rational proofs on the basis of conclusiveness and inconclusiveness

\begin{tabular}{|c|c|c|c|}
\hline & & \multicolumn{2}{|c|}{$\begin{array}{l}\text { Rational proof } \\
\qquad(\text { dalīl 'aqlī })\end{array}$} \\
\hline & & $\begin{array}{l}\text { Conclusive } \\
\quad\left(\text { qaț }^{\top} \grave{\iota}\right)\end{array}$ & $\begin{array}{l}\text { Inconclusive } \\
\qquad(z a n n \bar{\imath})\end{array}$ \\
\hline \multirow{2}{*}{$\begin{array}{l}\text { Scriptural proof } \\
\text { (dalīlnaqlī })\end{array}$} & $\begin{array}{l}\text { Conclusive } \\
\qquad\left(q a t^{c} \check{\iota}\right)\end{array}$ & $\begin{array}{l}\text { Both revelation and } \\
\text { reason attest } \\
\text { conclusively to one and } \\
\text { the same fact. }\end{array}$ & $\begin{array}{l}\text { Conclusive scriptural } \\
\text { proof takes precedence } \\
\text { over inconclusive } \\
\text { rational proof. }\end{array}$ \\
\hline & $\begin{array}{l}\text { Inconclusive } \\
\qquad(\text { zannī })\end{array}$ & $\begin{array}{l}\text { Conclusive rational } \\
\text { proof takes precedence } \\
\text { over inconclusive } \\
\text { scriptural proof. }\end{array}$ & $\begin{array}{l}\text { The stronger (rājihh) of } \\
\text { the two inconclusive } \\
\text { proofs takes } \\
\text { precedence over the } \\
\text { weaker (marjūh }) \text {. }\end{array}$ \\
\hline
\end{tabular}

to establish the foundations of theology (ușül al-dīn) in a conclusive (qaț $\bar{\imath}$ ) manner through textual evidence since reasoning (istidla $\bar{l} l$ ) from scripture is dependent on inconclusive (zannī) factors. Such "inconclusive" factors include, for al-Rāzī, the transmission of the lexicon, syntax, and morphology of the language; verification of the absence of figurative usage (majāz), ellipsis (idmār), homonymy or polysemy (ishtirāk), particularization of a general term (takhșisș), or transposition of meaning (naql); and, beyond such linguistic and hermeneutic concerns, establishing that there exists no valid rational objection (mu'ârid 'aqlī) to the obvious sense of the texts (zähir al-nașș). ${ }^{63}$ Debilitatingly, however, al-Rāzi holds that it is impossible to know that there is no rational objection, since it is always conceivable that there might exist an intrinsically ( $f i$ nafs al-amr) valid rational objection to what the Qur'ann states that simply has not occurred to the person encountering a given Qurānic verse or hadìth. ${ }^{64}$ Ibn Taymiyya informs us that in a work [entitled Sharh awwal al-Muhașșal]

63 See, e.g., al-Rāzī, Asās, 234-235; also al-Rāzī, Tafsīr, 24:181 (discussed in El-Tobgui, "Hermeneutics of Fakhr al-Dīn al-Rāzī," 139-140).

64 See, e.g., al-Rāzī, Mațālib, 116-117; Muhaș̣sal, 51; Arbaìn, 2:251-254; and Ma'âlim, 25. 
composed some thirty years before the Dar' ta'ärud, he had responded to al-Rāzì's allegations that arguments deduced from revelation could never be definitive and had established, to the contrary, that such arguments could indeed yield certitude. ${ }^{65}$ Be that as it may, al-Rāzī's argument regarding the inconclusiveness of scriptural indicants-quite apart from its invalidity-is of no use, for even if al-Rāzī were right, the indicant given priority (namely, the rational one) would still be privileged on account of its being conclusive, not on account of its being rational or on account of its "grounding" revelation. For those who adhere to the universal rule, by contrast, the primary basis on which they give priority to the rational indicant is its alleged grounding of revelation, a position that does not stand up to scrutiny. ${ }^{66}$ Any rational person would agree, moreover, that if a conclusive and an inconclusive indicant contradict, then the conclusive one must be given preference. But demonstrating that a scriptural indicant can never be conclusive, Ibn Taymiyya avers, would be to accomplish the impossible (dūnahu kharț alqatād). ${ }^{67}$

Moreover, Ibn Taymiyya maintains, everyone agrees that certain points of creed-for example, that various acts of worship are obligatory, that various forms of moral license and wrongdoing are prohibited, that the Creator is one, that resurrection after death is real, and so forth-constitute fundamentals that are known of necessity to be part and parcel of the religion (malüm bil-idțirār min al-dīn). Now, if someone were to claim that a definitive rational proof contradicting one of these matters had been established and that it was therefore necessary to give precedence to this proof on the basis that reason grounds revelation, such a prioritizing of reason would, by universal agreement, be tantamount to belying the Prophet himself and the authenticity of the revelation he transmitted, which amounts to open disbelief. Ibn Taymiyya explains that, in response to this objection, such groups typically appeal to the simple impossibility that there could be a valid rational proof that contradicts matters known to belong to the established fundamentals of the faith. But by this, he reasons further, it becomes clear that it is impossible for anything that has been established by a conclusive (scriptural) proof to be contradicted by a conclusive (rational) proof. Yet many fall into this error: they make assumptions that entail certain consequences and then proceed to affirm these conse-

65 See Dar', 1:22, lines 3-6. The work in question—cited in, among others, Ibn Rushayyiq, Asmā'mu'allafāt, 19 and Ibn 'Abd al-Hādī, 'Uqūd, 37-is, unfortunately, no longer extant.

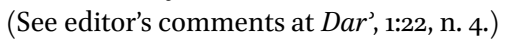

66 Dar', 1:80, lines 1-5.

67 Dar', 1:80, lines 6-7. 
quences, without realizing that the assumption itself is invalid and that an invalid assumption may indeed entail invalid consequences. ${ }^{68}$

Ibn Taymiyya also drives two related arguments on the basis of an issue that is common in legal discussions of the texts of revelation (Qurān and hadìth): namely, the issue of the authenticity, reliability, or integrity (thubüt) of the texts, on the one hand, and that of their meaning or signification (daläla), on the other. ${ }^{69}$ According to the first of these two arguments, ${ }^{70}$ either a person possesses knowledge (based on reason) that the Prophet's mission was authentic and, consequently, that what was revealed to him is factual and true in and of itself (thubüt mã akhbara bihifinafs al-amr), or he does not. If he does not possess knowledge (that is, certain knowledge) that revelation is authentic, then there can be no bona fide conflict between anything revelation asserts and any rational conclusion that he knows (i.e., with certainty) to be true. In such a scenario, the rational conclusion known with certainty would take precedence over anything asserted in a source (in this case, revelation) that is not known with certainty to be trustworthy and authentic. And if the rational proposition in question is also not known (that is, known with certainty to be true), then there cannot, a fortiori, be a conflict in this case either, since it is impossible for two unknowns to contradict each other. In short, if the mind knows (a) that revelation is indubitably authentic and (b) that revelation has affirmed (akhbara bi) a proposition $p$, then knowledge of the factual truth (thubüt) of $p$ is entailed necessarily by the combination of (a) and (b), just as other known propositions are entailed necessarily by a combination of their premises if these latter be true. $^{71}$

Ibn Taymiyya goes on to spell out the implications of someone saying, "Do not believe in the factual truth of what revelation has informed you of since your believing so is incompatible with (yunāfi ) that by which you have come to know of its veracity [namely, reason]. ${ }^{\prime 2}$ In fact, Ibn Taymiyya remarks, what is definitively incompatible with reason (i.e., that reason which has led to knowledge of the truth of revelation) is the notion that one should, while accepting revelation as true and authentic, feel free to belie any of the specific propositions contained therein. This would eventually undermine our confidence in anything revelation may assert, since if it is possible for revelation

68 "al-taqdìr al-mumtani qad yalzamuhu lawāzim mumtani'a." Dar', 1:81, lines 1-2. For this argument overall, see Dar', 1:80, line 6 to 1:81, line 3.

$69 \quad$ See figure 3, p. 157 above.

70 Argument 4 (Dar', 1:134-137).

71 See Dar', 1:134, lines 1-9.

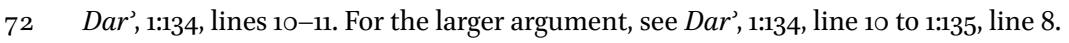


to err in a given instance, then it is surely possible for it to err in other, innumerable instances as well. ${ }^{73}$ The result of all this is that people who approach the texts in such a manner do not gain any knowledge from them about the attributes of God known through revelation (șifät khabariyya) or about the day of judgement. This is so because they believe that such statements contain some elements that ought to be accepted at face value and other elements whose obvious meanings are inapplicable and, consequently, subject to figurative interpretation through $t a^{3} w \bar{l}$. Yet they have no rule or principle from revelation itself by which to make the crucial distinction between those elements that are meant literally and those that are intended in a figurative sense. ${ }^{74}$

If, indeed, it is inconceivable that what a prophet asserts by way of revelation should contravene reason, Ibn Taymiyya continues, then this would amount to an admission that it is, in fact, impossible for scriptural and rational indicants to contradict each other. Someone might then argue that what is really meant is that it is impossible for there to be a contradiction between reason and something that is not a scriptural indicant at all (though it is erroneously thought to be) or between reason and a scriptural indicant that is inconclusive (zannī), either on the level of its chain of transmission (isnād) (in the event, say, of a mendacious or inaccurate narrator in the chain) or on the level of its content (matn) (in the event, say, of an equivocal term in the text). In this case, the response would be that if the term "scriptural indicant" is applied to what does not actually constitute a (reliable) proof in and of itself ( $m \bar{a}$ laysa bi-dalil finafs al-amr), then it could likewise be the case that some of what have been called "rational indicants" but that contradict revelation could, mutatis mutandis, also turn out, upon closer inspection, not to constitute a proof in and of itself ( fi nafs al-amr). In this case, if such proofs, touted as apodictic and rationally conclusive ${ }^{75}$ though they be merely conjectural, were to contradict a scriptural indicant whose premises are both valid and well known, then it would be incumbent to give priority to the scriptural

73 See Dar', $^{\prime}$ :135, lines 9-13.

74 It is important to note here that many thinkers did, in fact, propose certain texts of revelation as containing directions to carry out precisely this type of rational weighing of reality and the figurative interpretation $\left(t a^{\prime} w \bar{l} l\right)$ of revelation accordingly. Perhaps this is most obviously the case with Ibn Rushd, but it is also assumed, perhaps to a lesser degree, by a number of theologians as well. (We recall, for instance, al-Ghazālī's discussion, in al-Qisțās al-mustaqīm, of the mizān mentioned in the Qur'ān as being equivalent to the various figures of Aristotelian syllogistic inference.) See al-Ghazālī, al-Qisțās al-mustaqìm, 41-46. Al-Ghazālīs Qisțās has been translated into French by Chelhot, "«alQisțās al-Mustaqīm»," and into English, as The Just Balance (al-Qisțās al-Mustaqīm), by D.P. Brewster.

Roughly paraphrasing "barāhīn 'aqliyya" and "qawāțic 'aqliyya." Dar', 1:136, line 15. 
indicant over the rational one-by virtue, once again, of its superior epistemic warrant, not on account of its origin in the category of statements collectively referred to as "revelation."

It is thus manifest, Ibn Taymiyya concludes, that whatever explanation is given for one category of indicants-scriptural or rational-enjoying automatic preponderance, it is possible to reverse this explanation and apply it in an equivalent manner to the other category as well. It is therefore invalid to accord automatic priority to an entire category of indicant over another. Rather, one must investigate the two specific pieces of evidence found to be in contradiction on a particular point and give precedence to whichever one is conclusive ( $\left.q a t^{t} i\right)$ or, if neither is fully conclusive, then to whichever one is of greater probative value (räjih h), irrespective of whether the indicant thus preferred be the scriptural or the rational one. In this manner, the fallacious principle that has served as a means for various forms of heterodoxy is vitiated. ${ }^{76}$

The previous argument revolved around the question whether revelation is known to be authentic, that is, a question of textual integrity, or thubüt. Ibn Taymiyya now completes this series of arguments ${ }^{77}$ by starting from the assumption that the authenticity (thubüt) of revelation is known, then considering the question of signification, or daläla - that is, whether revelation can be established to have definitively addressed the issue in which a conflict with reason is alleged. Assuming revelation to be authentic, we are faced with one of three scenarios: (1) revelation is known to affirm the issue under debate, (2) it is merely conjectured to affirm it, or (3) it is neither known nor conjectured to affirm the issue at hand. Now, if it is known that revelation has affirmed the matter, then it is impossible for there to be anything in reason that would contradict or be incompatible with (yunāi $\bar{\imath}$ ) what is known to be the case (whether known through revelation or by any other means), for if something is known either to be true or not to be true, either to exist (thubüt) or not to exist (intifä), then it is not possible that a proof be established that would contradict this. If, on the other hand, something is only conjectured to be the case on the basis of revelation, then it is possible for something in reason to contradict it, in which case it is incumbent, once again, to give priority to knowledge over conjecture-not on account of its being rational rather than scriptural but on account of its being knowledge, just as it would be incumbent to give priority to what is known by revelation over what is merely conjectured to be the case by reason. If the rational indicant itself is merely conjectural, falling short of conclusive certainty, and if the two indicants are of equivalent probative value, then the

76 See Dar $^{3}, 1: 136$, line 5 to 1:137, line 8 for this and the preceding paragraph.

77 See Argument 5 (Dar', 1:137). 
matter remains irresolvable; otherwise, priority is given to the one that enjoys the greater epistemic warrant. And if revelation contains nothing that can be considered knowledge, or even mere conjecture, on the point in question, then there is nothing in it for reason to contradict with in the first place. This proves once again, for Ibn Taymiyya, that according automatic priority to reason (or even to revelation) in all circumstances is both misguided and rationally indefensible. ${ }^{78}$

In conclusion, then, Ibn Taymiyya seeks to replace the binary "reason vs. revelation" with the alternative binary "certainty vs. probability." He does so by arguing that individual arguments based either on what is considered reason or on what is considered authentic scripture run the entire scale of epistemic value from "certain" to "fallacious" and that, therefore, precedence must be accorded, in each case, to whichever argument enjoys greater probative weight, regardless from which of the two sources of knowledge, reason or revelation, it comes to us. Once Ibn Taymiyya has, in essence, equated the two sourcesreason and revelation-epistemically while simultaneously subjecting each discrete element of both categories to a common test of probative value, he completes this second maneuver against the universal rule by declaring that the issue is not, as everyone seems to have assumed, one of reason versus revelation but rather one of knowledge versus conjecture, certainty versus probability, more probative versus less probative indicators of truth. Taken together, Arguments 1 through 5-addressing what it means for reason to "ground" revelation and establishing the crucial binary "certainty vs. probability" over against the inherited dichotomy "reason vs. revelation" - aim to undermine the main premises upon which the universal rule is predicated.

Not "Scriptural vs. Rational" but "Scripturally Validated vs. Innovated"

Ibn Taymiyya's insistence that the relevant distinction to be made is between knowledge and conjecture rather than between reason (as a category) and revelation (as a category) has immediate implications for the epistemological status, as well as the religious-moral evaluation, of various arguments and proofs. In Argument $15,{ }^{79}$ Ibn Taymiyya elaborates a fundamental distinction through

78 Dar', 1:137, lines 9-18 (comprising all of Argument 5).

79 See Dar', 1:198-20o for Argument 15 and the full presentation of Ibn Taymiyya's novel binary "shar 'i vs. bid'i" in place of the more usual dichotomy "shar'i vs. 'aqlī" (or "scriptural vs. rational"). 


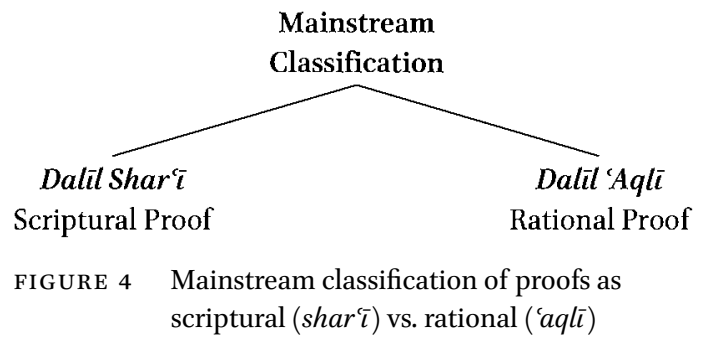

which he seeks to shift the entire frame of reference in the debate concerning reason and revelation. He proposes that the real issue is not a question of "scriptural" versus "rational" (that is, shar ${ }^{\complement} \bar{\imath}$ as opposed to 'aqlī) proofs and methods, as scholars had framed the debate up until his time. Rather, he tells us, the fundamental distinction to be made is between "scripturally validated" versus "innovated" (that is, shar 'i as opposed to bid 'i) proofs and methods. Scripturally validated proofs, in turn, comprise both revealed $(\operatorname{sam} \bar{\imath})$ and rational ('aqlī) indicants. For Ibn Taymiyya, the shar $\bar{\imath}-$ bid $^{\prime} \bar{c}$ binary is based on the premise that an indicant's classification as "scriptural" or "rational" is not, in and of itself, a property that entails praise or blame, validity or invalidity. Rather, this only reveals the epistemological avenue - reason or revelation — through which an alleged piece of knowledge has come to us (although when revelation is the source, reason must also be used in order to understand it). ${ }^{80}$

Ibn Taymiyya's reclassification of indicants and proofs results in a new binary that is no less than fundamental to his thought and methodology. According to this new classification, the converse of a scriptural (shar $\bar{\imath}$ ) proof is not a rational one but an innovated (bid'i) one, for it is innovation (bid'a) rather than reason that stands opposite revealed religion $($ shir' $a) .{ }^{81}$ The word shar ' $i$ in Ibn Taymiyya's new schema is thus no longer simply a synonym of $\operatorname{sam}^{\prime} \bar{\imath}$ (referring, in the religious context, to that which we know only through revelation) but comes to mean something like "scripturally validated" or "scripturally confirmed," in other words, valid and true and vouched for as such by revelation. Being scripturally validated $(\operatorname{shar} i \bar{l})$ is a positive attribute of an indicant or proof, whereas being innovated $($ bid $\bar{\imath})$ — not in the sense merely of being new but of lacking scriptural validation - is a negative qualification,

8o Ibn Taymiyya seems to imply that this is necessary in order to determine that something is a part of authentic revelation and, having done so, properly to understand the import thereof. In other words, reason is employed in the determination both of the reliability and authenticity (thubüt) of the revealed texts and of their signification (daläla) or meaning, as we have discussed in the preceding section.

81 "idh al-bid'a tuqābilu al-shir'a." Dar', 1:198, line 6. 


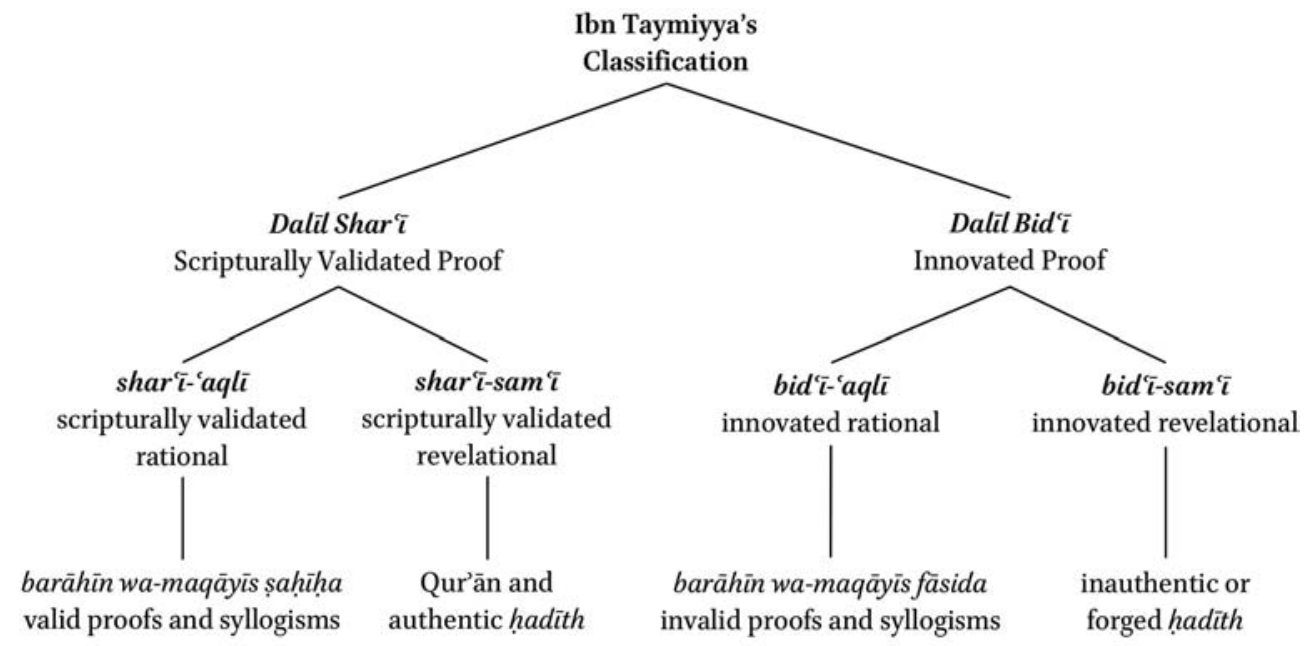

FIGURE 5 Ibn Taymiyya's classification of proofs as scripturally validated (sharī̄) vs. innovated $\left(\operatorname{bid}^{\prime} \bar{\imath}\right)$

for whatever stands opposed to authentic scriptural religion ( $\operatorname{sharit} a)^{i}$ ) is, of necessity, invalid and false. A scripturally validated indicant, in turn, may consist of either a revealed text or a conclusion reached through reason, for a proof's being scripturally validated can mean one of two things: either (1) that revelation has positively affirmed and explicitly indicated it (kawn al-shar'athbatahu wa-dalla 'alayhi) or (2) that revelation has permitted it and declared it valid and licit (kawn al-shar'abähahu wa-adhina fihi). ${ }^{82}$ Scriptural validation, in other words, can come about either by way of affirmation from the shar (revelation) or by way of revelation's approbation and approval.

If one uses "scriptural" (shar $\bar{l}$ ) according to the first meaning - namely, that which scripture has positively affirmed and indicated - then it is possible that the indicant or proof in question is also knowable through the use of reason, with the role of scripture being to point it out (dalla 'alayhi) and call attention to it (nabbaha 'alayhi). In this case, the indicant is classified as a "scripturally validated rational" (shar 'i-'aqli) indicant. As examples of scripturally validated rational indicants, Ibn Taymiyya cites the various parables (amthāl) mentioned in the Qurān, arguments for the oneness of God and the authenticity of the Prophet Muhammad, the affirmation of God's attributes, and similar matters. All these are proofs whose truth is known by reason, as they consist of rational demonstrations and syllogisms (barāhinn wa-maqāyiss 'aqliyya), yet they are also

82 See Dar' $^{\prime}$ 1:198, lines 3-9. 
classified as scripturally validated by virtue of being mentioned and explicitly affirmed in the Qur'ān. If, by contrast, a given indicant is known exclusively by way of the revealed texts, then it is classified as a "scripturally validated revealed" ( $\operatorname{shar}^{i} \bar{\imath}$-sam $\left.\bar{\imath}\right)$ indicant. Such indicants would include, for instance, proof texts adduced from the Qurān or hadith to establish the reality of events like the day of judgement or other such matters that we can know about only through revelation. In sum, all valid indicants may be categorized as either scripturally validated and rational (shar $\left.\bar{l}^{-}-a q \bar{\imath}\right)$ or scripturally validated and revealed $\left(\operatorname{shar}^{\bar{\imath}} \bar{\imath}\right.$-sam $\left.\mathfrak{\imath}\right)$.

Many kalām theologians, Ibn Taymiyya insists, have made the error of presuming that the category of scriptural indicants consists exclusively of this

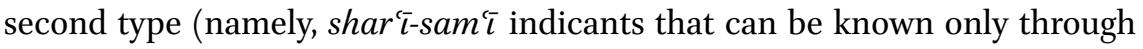
the texts of revelation and not through reason) and that revelation functions as an indicant (dalïl) only in this manner, that is, purely by informing us of matters about which we could otherwise have no knowledge. For this reason, they separate the foundations of theology (ușül al-dinn) into two categoriesrational and scriptural-and define the rational strictly as that which is not, and cannot be, known by way of revelation (and, conversely, define the scriptural strictly as that which is not, and cannot be, known through reason). Yet Ibn Taymiyya insists that this is an error, for the Qurān itself uses, indicates, and draws attention to rational proofs. Indeed, some things classified as rational proofs can be inferred by reason on the basis of empirical evidence, ${ }^{83}$ as the Qur'ān itself indicates in verses such as "We shall show them Our signs in the horizons and in themselves until it becomes clear to them that it is the Truth" (Q. Fusșilat 41:53). The purpose of such a verse, for Ibn Taymiyya, is to advance a rational argument for the existence of God based on the existence and contingent nature of the empirical world around us. ${ }^{84}$

If, however, we use the term "scriptural" or "scripturally validated" ( $\operatorname{shar}^{\mathrm{\imath}} \boldsymbol{\imath}$ ) according to the second meaning mentioned above (namely, what scripture has permitted and deemed licit but has not itself positively affirmed or established), then this category, according to Ibn Taymiyya, is divided into several subcategories: (1) that which has reached us of the authenticated prophetic Sunna, (2) that which the Qurān has indicated and drawn attention to in terms of rational proofs and arguments, and finally (3) that which can be inferred on the basis of our empirical observation of existent things ( $m \bar{a}$ dallat 'alayhi wa-

83 "wa-in kāna min al-adilla al-'aqliyya mā yuđamu bi-l-iyān wa-lawāzimihi." Dar', 1:199, lines 9-10.

84 See Dar', $^{\prime}$ :198, line 9 to 1:199, line 12 for this and the preceding paragraph. 
shahidat bihi al-mawjūdāt) — this last subcategory effectively elevating empirical observation to the category of shar $\bar{i}$, or scripturally validated, evidence as well. ${ }^{85}$

To summarize, an indicant that is scripturally validated (dalïl shar $\bar{\imath})$ cannot be contradicted by or subordinated to one that is not scripturally validated (ghayr shar $\bar{\imath})$. As for indicants that are rational ('aqlī) or have the nature of a transmitted report (sam $\bar{\imath}$ ) but that are not specifically validated by revelation (shar $\bar{\imath}),{ }^{86}$ such indicants may sometimes outweigh and sometimes be outweighed by countervailing evidence, sometimes be valid and sometimes invalid. ${ }^{87}$ Finally, statements of authentic revelation, both declarative and imperative, cannot be overridden or contradicted (yu'ärad) by anything. Unfortunately, however, Ibn Taymiyya laments, some include in the category of scriptural proofs and indicants (adilla shar iyya) that which does not belong to it, while others exclude from it that which is, in fact, a proper subcategory of it. This subcategory, we may assume, includes scripturally validated rational (shar'i-aq $\bar{l} \bar{\imath})$ arguments-an important category of shar'i indicants that Ibn Taymiyya blames the mutakallimün for having made the fundamental error of excluding from the category of scriptural proofs..$^{88}$

In conclusion, Ibn Taymiyya completes his redefinition of the terms of the debate on reason and revelation by proposing a third conceptual shift, namely, that indicants and proofs are not diametrically opposed in terms of being "scriptural" (shar ${ }^{i} \overline{)}$ ) versus "rational" ('aqlī) but rather in terms of being "scripturally validated" (shar $\bar{\imath})$ versus "innovated" (bid $\bar{\imath})$. The category of scripturally validated proofs comprises both the authentic texts of revelation, properly comprehended, and valid rational arguments built on sound premises. Ibn Taymiyya thus divides what passes for "reason" into two categories, valid/true and invalid/false, and absorbs that which is valid ${ }^{89}$ into the larger umbrella category of shar $\bar{\imath}$, or scripturally validated, proofs. By rigorously insisting on the epistemic quality of a proof or piece of evidence to the exclusion of all other considerations, including whether the proof or evidence originates in reason or in revelation, Ibn Taymiyya attempts to circumvent the rigid cat-

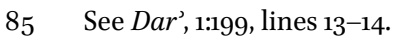

86 Such as, for example, a historical or other sort of "report" or piece of information that is neither affirmed, nor denied, nor addressed by revelation in any way.

87 As in the case of rational arguments containing false premises or built on invalid inferences, or in the case of hadith texts transmitted as putative revelation but found, upon investigation, to be inauthentic.

88 See Dar', 1:200, lines 13-18.

89 Ibn Taymiyya's understanding of what exactly constitutes valid and invalid reasoning and rational proofs deserves a separate study and cannot be taken up in detail here.
} 
egories of "reason" (taken as a whole) and "revelation" (taken as a whole) by subjecting each individual element of both categories to a common test of epistemic warrant, then asserting that revelation legitimates and endorses everything that is true and certain and abjures everything that is false and unfounded-regardless, once again, of whether it originates in reason or in what is claimed to be divine revelation.

In summary, we have seen in sections 5,6 , and 7 above that Ibn Taymiyya makes three fundamental moves in his refutation of the universal rule. First, he demolishes the fixed categories of "revelation" and "reason" by placing all the discrete elements of both on an equal footing. Second, he insists that each element, whether from reason or from revelation, be individually investigated for its probative value, thus replacing the binary "reason vs. revelation" ('aql-naql) with the binary "certainty ('knowledge') vs. probability" ('ilm-zann) —and, in the case of probabilistic (zannī) matters, the further sub-binary of "more probative vs. less probative" (räjihh-marjūh $)$ indicators of knowledge and truth. Finally, he subsumes valid rational arguments based on sound premises under the larger category of "scripturally validated" (shar $\bar{\imath})$ proofs, placing them into a new category he terms "scripturally validated rational" ( $\left.\operatorname{shar}^{\prime} \bar{l}^{-} a q \bar{l}\right)$, the counterpart of the "scripturally validated revealed" ( $\left.\operatorname{shar}^{\prime} \overline{-}-\operatorname{sam}^{\prime} \bar{\imath}\right)$. By these three maneuvers, Ibn Taymiyya seeks to demolish the universal rule altogether and to redefine the very terms of the debate surrounding reason and revelation in Islam. He accomplishes this tour de force first by poking holes in all the major assumptions that form the basis of the universal rule, then by redefining the very categories in terms of which the question of reason and revelation had been conceived and debated up to his time.

\section{Further Arguments Regarding the Rational Contradictoriness of the Universal Rule ${ }^{90}$}

In this section, I present a number of disparate arguments Ibn Taymiyya advances against the universal rule. The majority of these arguments are composed of succinct statements that, taken together with the arguments discussed in section 9, provide an overview of the nature and content of nearly

$90 \quad$ Based on Arguments 8 (Dar', 1:148-156), 10 (1:170-192), 11 (1:192-194), 13 (1:195), 14 (1:195198), 21 (5:204-209), and parts of Argument 29 (5:268-286). Arguments 28 (Dar', 5:242268), 31 (5:289-320), 32 (5:320-338), 33 (5:338-340), 34 (5:340-343), 35 (5:343-345), 37 $\left(5: 357-35^{8}\right), 39(5: 363-370)$, and $42(5: 387-392)$ also belong to this group. 
half Ibn Taymiyya's thirty-eight arguments against the universal rule. In the paragraphs that follow, I present Arguments 11 through 14, as well as parts of Arguments 8 and 21.

In Argument $8,{ }^{91}$ Ibn Taymiyya asserts that the majority of issues allegedly involving a contradiction between reason and revelation are recondite and ambiguous matters that perplex even many of the rationalists themselvesissues such as God's names, attributes, and actions, the ontological reality of otherworldly reward and punishment, God's throne ('arsh) and footstool (kursī), and other such matters pertaining to the unseen. Most people who have ventured into such territory on the basis of mere opinion derived from their own rational reflection either end up in dispute and disagreement with one another or remain at a loss and perplexed (mutahawwikün). ${ }^{92}$

Ibn Taymiyya makes the further point that most of these thinkers defer without qualification to the main figures of their particular school of thought, even when their own reflections sometimes lead them to different conclusions. Among the followers of Aristotle, for example, many come to different conclusions from their master in the fields of logic, physics, and metaphysics, ${ }^{93}$ yet they refrain from opposing Aristotle's doctrine and attribute the fact that their conclusions differ from his to their own mental deficiency and lack of understanding. ${ }^{94}$ This, remarks Ibn Taymiyya, in spite of the fact that

the people of intellect who are endowed with pure reason ( $a$ hl al-'aqlalmuttașifüna bi-șarịh al-'aql) know that the science of logic, for instance, contains much that is patently and indubitably erroneous, as has been mentioned elsewhere. As for what he [Aristotle] and his followerssuch as Alexander of Aphrodisias [fl. ca. 200 CE], Proclus [d. 485 CE], Themistius [d. $387 \mathrm{CE}$ ], al-Fārābī, Ibn Sinnā, al-Suhrawardī al-Maqtūl, Ibn Rushd (the grandson), and others- have said in the realm of metaphysics (ilähiyyāt), this contains such great error and enormous deficiency as are clear to the generality of rational human beings (jumhür 'uqală' bani $\bar{A} d a m)$. Indeed, their discourse is beset by well-nigh incalculable contradictions. ${ }^{95}$

\footnotetext{
$91 \quad$ Dar $^{3}, 1: 148-156$.

92 Dar', 1:151, lines 5-10.

93 Ibn Taymiyya often cites pre-Islamic thinkers, both Greek and Hellenistic, who disagreed with Aristotle's logic and larger philosophy, either in whole or in part. See von Kügelgen, "Ibn Taymiyas Kritik," 176-179.

94 Dar', 1:151, lines 13-16.

95 Dar', 1:151, line 16 to 1:152, line 4. (See index of Arabic passages.)
} 
This same attitude of excessive deference to authority can be observed among the followers of all the major schools of Muslim thought as well, from the major Mu'tazili theologians to those who are "closer to the Sunna," from the Ash'arīs, Kullābīs, and Karrāmiyya to the followers of the Four Imams and the leading ascetics and early Sufi figures. ${ }^{96}$ Ibn Taymiyya contends that not only do many of their doctrines contain much that contradicts the Qurān, the Sunna, and the consensus $\left(i j m \bar{a}^{c}\right)$ of the community, but they also contain numerous positions that contradict pure reason. Yet none of the followers of these various authorities would give unconditional priority to their own conclusions over those of their revered leader. How then, Ibn Taymiyya asks, can anyone claim that authentic revelation contains elements that every common man knows through his reason to be false and that each man should thus give precedence to his own opinion over revelation-despite his awareness of the deficiency of his own intellect and the confusion into which adherents of his school and contending schools have fallen with regard to such matters? Yet all groups claim to know that revelation is true, and what is known to be true cannot legitimately be opposed by what is ambiguous and confused and is thus, by contrast, not known to be true. ${ }^{97}$

Argument $11^{98}$ holds that much of what people refer to as proofs (adilla)whether rational or scriptural - does not, in fact, constitute proof but is something they only surmise to constitute proof. Everyone, from the Companions to the later rationalists (affirmationists and negationists alike), agrees that the texts of revelation affirm (tadullu 'ala $)$ the divine names and attributes, details pertaining to the hereafter, and the like. The dispute arises only with regard to whether there is anything in reason that dictates that the texts ought to be read as conveying a "true" non-literal or metaphorical meaning that differs from what a straightforward exegesis of them would suggest. However, there is vast disagreement among rationalist thinkers on the question of what constitutes valid rational knowledge. Thus, something that is known and agreed uponnamely, the straightforward meaning or signification (daläla) of the revealed texts - cannot legitimately be opposed by putative conclusions of reason that are subject to so much dispute and uncertainty. Nevertheless, Ibn Taymiyya remarks in conclusion, the people of truth do not impugn rational arguments

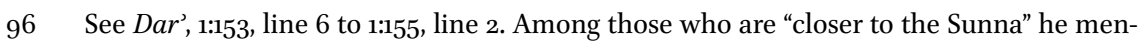
tions al-Ḥusayn b. Muhammad al-Najjār (d. ca. 220/835) and Dirār b. 'Amr (d. ca. 200/815), whose followers include Muhammad b. 'Īsā Burghūth (d. 240/854 or 241/855), "who debated Aḥmad b. Ḥanbal," and Ḥaf̣s al-Fard (fl. ca. 20o/815), "who debated al-Shāfi'ī” (see Dar', 1:153, line 6 to 1:154, line 2).

97 See Dar', 1:151, lines 2-3 and 1:155, lines 2-13.

98 Dar', 1:192-194. 
or proofs (adilla 'aqliyya) as a category nor that which reason knows to be valid; rather, they reject only what their opponents claim to be in contradiction with revelation. Yet with respect to all such claims, he asserts, not one of them is supported by an intrinsically valid argument (dalïl șahịh fì nafs al-amr), ${ }^{99}$ nor by an argument that is accepted by the generality of rational persons ('ämmat $a\left(-u q a\left(\vec{a}^{3}\right)\right.$, nor yet by an argument that has not been undermined and refuted by reason itself.

Argument $12^{100}$ holds that all the conclusions of reason that allegedly contradict revelation can be demonstrated by reason itself to be invalid. Now, what is known by reason to be invalid cannot be used to oppose other conclusions similarly derived from reason or to oppose revelation. This is a general principle that Ibn Taymiyya promises to substantiate in detail when he turns to the specific arguments propounded by those who contravene orthodox belief ("the Sunna"), arguments whose specious and contradictory nature he says he will demonstrate on the basis of reason itself.

According to Argument $13,{ }^{101}$ those elements of revelation that are claimed to contradict rational evidence-elements such as affirmation of the divine attributes, the details of the hereafter, and the like-are known of necessity to be part and parcel of the religion of Islam (malüm bi-l-idțirār min dìn alIslām). ${ }^{102}$ Thus, it is incoherent for one to hold any of these matters to be false once one has accepted the truthfulness of the Prophet and the concomitant authenticity of the revelation he brought.

In Argument 14, ${ }^{103}$ Ibn Taymiyya contends that not only the words but also the meanings of the Quraan, as well as the intentions and objectives of the Prophet (maqāṣiduhu wa-murāduhu), have been transmitted in the same recurrent (mutawātir) fashion as the Qurānic text, the obligatory nature of the five daily prayers, the obligation to fast during Ramadan, and similar well-known and undisputed matters. Some of these elements are mutawātir among both scholars and the general public, while other, more specialized elements are mutawātir only among the experts of Qurānic exegesis and the prophetic Sunna. Yet other, even less commonly circulated elements are known exclusively to particular individuals and may even be deemed suspect (maznūn) or fabricated (makdhūb) by those lacking the requisite knowledge to assess them. According to Ibn Taymiyya, this principle holds in all the various disciplines, such as Qur'ānic exegesis, ḥadīth criticism, grammar, medicine, law, and discur-

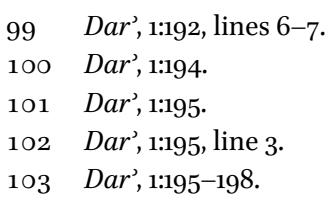


sive theology. From an epistemological point of view, recurrent transmission of the mutawatir type yields knowledge that is certain and, therefore, not subject to refutation. Thus, any claim about the content of revelation (concerning, for instance, the meanings of the Qur'ān or the intentions and objectives of the Prophet as known through his Sunna) that contradicts what the scholars most intimately familiar with these sources know to be true would, of necessity, be a false claim.

Argument $21,{ }^{104}$ which is less an argument than an assertion, affirms the premise that it is impossible for two declarative statements of revelation to contradict each other, though it may be the case that one explains or elucidates the meaning of the other. This contrasts with the case of contradictory imperative statements, whereby one may have been abrogated and superseded by another. Ibn Taymiyya insists, however, that only revelation (and not, we are to understand, reason) may abrogate revelation. Whoever seeks to abrogate any aspect of the religion on the basis of his own whims and opinions is guilty of heresy (ilhād), just like someone who rejects or relativizes the declarative statements of revelation by making their interpretation subject to the fruits of his own (unfounded) speculation. Ibn Taymiyya accuses the Qarāmița (seemingly a reference to the Ismāilìs) of engaging in both such abrogation and speculation, and he excoriates other heretics (malāhida) for going so far as to claim prophethood for themselves or a station they consider even higher than prophethood (he is referring here to the philosophical enterprise, by which many of the philosophers claim access to a truth higher than that purveyed by revealed religion). ${ }^{105}$ Ibn Taymiyya concludes that opposing revelation on the basis of mere opinion is one of the paths that lead to disbelief (min shu'abal-kufr), even if the one who does so firmly believes in all the teachings of revelation other than those he claims to be contradicted by his rational conclusions. If revelation is true, then all arguments that lead to a contradiction with any part of it are, by necessity, invalid and false.

\section{On the Incompatibility of the Universal Rule with the Status and Authority of Revelation}

A large majority of Ibn Taymiyya's arguments against the universal rule, as we have seen above, take the form of rational critiques of its coherence and logical implications and are meant to demonstrate that the rule as formulated does

104 Dar', 5:204-209.

105 See Dar', 5:208, lines 10-16. 
not hold up on logical grounds. A number of arguments, however, consider the implications of the universal rule through the lens of revelation and within the larger religious context of the Islamic faith. These arguments leave aside the question of the logical and rational viability of the rule on its own terms and focus instead on the extent to which Ibn Taymiyya considers the rule to cohere (or not) with the overall epistemological structure of Islam, in the name of which he launches his massive critique and seeks to redress the troubled relationship between reason and revelation that he inherited. In the current section, we examine the main arguments Ibn Taymiyya makes in relation to the compatibility of the universal rule with Islamic revelation.

As part of Argument $3,{ }^{106}$ Ibn Taymiyya contends that anyone who has the slightest familiarity with the content of the message brought by the Prophet Muhammad knows necessarily (bi-l-idtirīarr) that he did not call people to faith by arguing from accidents or the negation of attributes or by teaching that the Creator was neither above the world nor distinct from it, neither inside the world nor outside it. Similarly, the Prophet made no mention of the negation of "body" in the technical, philosophical sense of the term, nor of the impossibility of a past or future infinite regress, nor of other such doctrines held by the philosophers and mutakallimün. Not only did he not endorse such teachings explicitly, but he also made no mention of anything that could plausibly be construed to imply or entail any of this. In fact, our knowledge that the Prophet did not address such matters is even more patent and obvious than our knowledge of a host of other details about his life as related in the books of Sunna, details such as the fact that he made the pilgrimage only once after the Hijra or that he never prayed the five obligatory prayers alone but always in a group. Yet if anyone tried to pass off falsified hadith reports or deduce rational arguments to the contrary, then the scholars who are intimately familiar with the texts and who know the truth of these matters in a necessary fashion ( ilman darüriyyan) would immediately recognize the falsehood of such claims, just as they would recognize the necessary falsehood of sophistical arguments even before resolving the specific points of doubt raised by such arguments. Hence, if anyone were to employ such rational methods of argumentation or publicly endorse the position of negationism (nafy) with regard to the divine attributes, then the necessary falsehood of his position would be even more blatant than the falsehood of one who claimed something contrary to any of the issues mentioned above relating to the (lesser-known aspects of the) Prophet's daily practice. This is known, Ibn Taymiyya concludes, by anyone with even the slightest knowledge of the conditions of the Prophet's life, let alone those with

$106 \quad$ Dar $^{3}, 1: 87^{-133}$. 
an intermediate level of knowledge, to say nothing of those who are the heirs of the Prophet, ${ }^{107}$ namely, the scholars who possess comprehensive knowledge of his words and deeds. ${ }^{108}$

As part of Argument 15, ${ }^{109}$ Ibn Taymiyya maintains that God, the Author of revelation, has prohibited the use of false arguments (such as an argument based on a faulty premise) just as He has forbidden falsehood and lying in general, not least with regard to Himself. This prohibition is indicated by the Qur'ānic verse "Was not the covenant of the Book taken from them that they would ascribe naught to God but the truth?" (Q. al-A'räf 7:169). God has also forbidden the use of arguments by one who seeks to use them without knowledge, as we read in verses such as Q. al-Isrä' 17:36: "And pursue not that of which you have no knowledge," or Q. al-A'räf 7:33: "that you say of God that which you know not," or Q. Āl Imrān 3:66: "Behold! You are those who dispute concerning that whereof you have knowledge; so why do you dispute concerning that whereof you have no knowledge?" Finally, God has forbidden the use of arguments merely for the purpose of disputation after the truth of a matter has been clarified, as indicated in the verse "They dispute with you (O Muhammad) concerning the truth after it was made manifest" (Q. al-Anfäl 8:6), as well as the verse "And those who disbelieve dispute with vain argument in order to confute therewith the truth" (Q. al-Kahf 18:56). The implication here is clear: Ibn Taymiyya interprets these verses, originally addressed to the Meccan pagans, as applying also to later philosophers and theologians, whose premises and arguments he considers specious and ill-founded. He therefore considers them to be "saying of God that which they know not" on the basis of "vain argument" and to be disputing with one another "concerning the truth after it was made manifest" (i.e., in the clear language of the Qurān and Sunna). In doing so, he charges, they weaken and undermine, rather than strengthen and reinforce, the truths plainly revealed to mankind on the tongue of God's final messenger. ${ }^{110}$

As part of Argument 21, ${ }^{111}$ Ibn Taymiyya asserts that privileging the rational opinions of men above revelation is tantamount to belying the prophets, which opens the door to disbelief. He paraphrases the beginning of al-Shahrastānì's famous heresiographical work, Kitāb al-Milal wa-l-nihal, to the effect that the root of every evil lies in opposing revelation with mere opinion and putting

\footnotetext{
107 From a prophetic hadìth, which states, in part, "The scholars are the heirs of the prophets" (inna al-'ulamā’ warathat al-anbiy $\bar{a}^{\prime}$ ). See al-Tirmidhī, Jāmi', 4:414; Abū Dāwūd, Sunan, 5:485; Ibn Mājah, Sunan, 81.

108 For this paragraph, see $\operatorname{Dar}^{3}$, 1:105, line 8 to 1:108, line 8.

109 Dar', 1:198-200.

110 For the argument presented in this paragraph, see Dar', 1:199, line 15 to 1:200, line 7.

111 Dar', 5:204-209.
} 
one's own biases and whims above the revealed texts. ${ }^{112}$ Ibn Taymiyya then cites five fairly lengthy Qurānic passages in support of this notion. ${ }^{113} \mathrm{He}$ explains that revelation is divided into two types of speech: imperative (insh $\vec{a} \bar{\imath})$ and declarative $(i k h b \bar{a} r \bar{\imath})$. The key to felicity and success consists in believing wholeheartedly in the declarative statements and obeying unreservedly the imperative ones, while the key to misery lies in opposing both with one's own opinion $\left(r a^{\prime} y\right)$ and biased whim (hawa $)$ and giving priority to these opinions and whims over the declarative and imperative dictates of revelation. According to Ibn Taymiyya, those theologians and rationalists who strayed did so with respect to the declarative part of revelation by opposing, on the basis of their own reasoning and opinions, that which God has declared in revelation regarding Himself and His creation. By contrast, the ascetics ( $a$ hl al-ibāda) and legal scholars who strayed did so with respect to the imperative parts of revelation by opposing God's command and following their own "shari ${ }^{-} a$ " based on their personal whims and opinions. Ibn Taymiyya's main point is that opposing revelation in either of these two domains (declarative or imperative) is the mark of a disbeliever, not a believer. This fact is established by several Qur'ānic verses, ${ }^{114}$ as well as by a hadith which declares that "disputation (mirä) with respect to the Qur'ān is disbelief."115 Ibn Taymiyya contends that these statements apply to any who dispute concerning the Qurān and who prefer their own opinions over the plain meaning of revelation, even if only inadvertently (by, for instance, upholding positions that, in effect, give priority to their reasonunderstood by Ibn Taymiyya as their own biased and misguided reason and not, of course, 'aql șarihh, or pure reason proper-over the texts of revelation). This judgement applies even to someone who holds a position that leads to doubt merely by way of implication (man qãla mā yüjibu al-mirya wa-l-shakk), let alone someone who explicitly claims that his reasoning and opinion should be given priority over the texts of the Qurān and Sunna.

According to Argument 22, ${ }^{116}$ God censures the disbelievers for turning people away from the path of God and seeking crookedness therein. ${ }^{117} \mathrm{Ibn}$ Taymiyya cites four Qurānic passages ${ }^{118}$ that concern those who turn away, or

\footnotetext{
112 Dar', 5:204, lines 1-4.

113 Q. al-An'ām 6:13o, al-A'rāf 7:35-36, Țā Hā 20:123-126, al-Zumar 39:71, and al-Mulk 67:8-9. (Dar', 5:204-205).

114 Q. al-Kahf 18:56; Ghäfir 40:4, 40:5. (Dar', 5:206).

115 “al-mirā'fíal-Qur'än kufr." Dar', 5:206, lines 14-15.

116 Dar', 5:210-211.

117 “yaṣuddūna 'an sabül Allāh wa-yabghūnahā 'iwajan." Dar', 5:210, line 2 (and similar at 5:211, line 2).

118 Q. Äl 'Imrān 3:98-99, al-A'rǟf 7:86, Hūd 11:18-19, and Ibrāhīm 14:2-3. (Dar', 5:210).
} 
who divert others, from God's path (that is, the normative religion that God has charged His messengers to convey), be it in terms of the propositional content of revelation or its normative commands and prohibitions. One who calls people not to believe in or to obey the prophets even in an abstract sense (man naha al-nās nahyan mujarradan) is guilty of this, so what of someone who encourages people to disbelieve in the specific substance of what was revealed to the prophets, arguing that his own reasoning contradicts it and is to be given priority over the contents of revelation? Furthermore, anyone who claims that sound reason ('aql șarīh), which it is incumbent upon people to follow, contradicts revelation and that God's path consists in following such "reason" has "sought crookedness in the path of God."119 This is so because he seeks to rectify the alleged crookedness of revelation and to redress its diversion from the truth by explaining it "correctly" on the basis of his own reasoning. In doing so, he implies that the divinely revealed path (al-sabil al-shariyya al-samiyya) transmitted via prophetic authority is not straight but crooked and that the straight path is the one newly innovated by those who contravene the argumentative methods and the explicit propositional content of revelation.

In Argument 23, ${ }^{120}$ Ibn Taymiyya cites many verses about how the Prophet was sent to make a clear declaration (balägh mubin) of truth and to guide people to the straight path. That being the case, if the obvious sense of what he brought were contradicted by sound reason as the negationists claim, then he would not have fulfilled these functions and would have misled people rather than guiding them aright. It is patently clear, Ibn Taymiyya argues, that the texts of revelation do not indicate negationism with respect to the divine attributes in such a way as to lead people to it in a clear and straightforward manner. On the contrary, he argues, the obvious sense of revelation entails nothing but clear and unambiguous affirmation of the attributes in a manner so patent as to be admitted readily by the generality of Muslims. Even the Mu'tazila and other negationists concede that such affirmationism constitutes the obvious sense of scripture. Thus, if negationism were correct (although the texts, Ibn Taymiyya contends, clearly endorse the opposite), then the Prophet would be someone who knew the truth but suppressed it and instead manifested its polar opposite. Ibn Taymiyya affirms that such a position - the position of "tajhil and tadlill" that we encountered in the first section of this chapter-openly contradicts the tenets of the message brought by the Prophet Muhammad. In fact, he concludes, the contradiction is so patent as to count among those elements that are "known by necessity to be part and parcel of the religion (of Islam)."

119 "fa-qad baghā sabïl Allāh 'iwajan" (Dar', 5:211, line 2), reminiscent of several Qurānic verses, namely, Q. Āl Imrān 3:99; al-A'räf 7:45, 7:86; Hüd 11:19; Ibrāhïm 14:3; and al-Kahf 18:1. 